\title{
Hazardous Lending: The Impact of Natural Disasters on Banks'Asset Portfolio
}

Citation for published version (APA):

Bos, J., Li, R., \& Sanders, M. (2018). Hazardous Lending: The Impact of Natural Disasters on Banks'Asset Portfolio. Maastricht University, Graduate School of Business and Economics. GSBE Research Memoranda No. 021 https://doi.org/10.26481/umagsb.2018021

Document status and date:

Published: 27/08/2018

DOI:

10.26481/umagsb.2018021

Document Version:

Publisher's PDF, also known as Version of record

\section{Please check the document version of this publication:}

- A submitted manuscript is the version of the article upon submission and before peer-review. There can be important differences between the submitted version and the official published version of record.

People interested in the research are advised to contact the author for the final version of the publication, or visit the DOI to the publisher's website.

- The final author version and the galley proof are versions of the publication after peer review.

- The final published version features the final layout of the paper including the volume, issue and page numbers.

Link to publication

\footnotetext{
General rights rights.

- You may freely distribute the URL identifying the publication in the public portal. please follow below link for the End User Agreement:

www.umlib.nl/taverne-license

Take down policy

If you believe that this document breaches copyright please contact us at:

repository@maastrichtuniversity.nl

providing details and we will investigate your claim.
}

Copyright and moral rights for the publications made accessible in the public portal are retained by the authors and/or other copyright owners and it is a condition of accessing publications that users recognise and abide by the legal requirements associated with these

- Users may download and print one copy of any publication from the public portal for the purpose of private study or research.

- You may not further distribute the material or use it for any profit-making activity or commercial gain

If the publication is distributed under the terms of Article $25 \mathrm{fa}$ of the Dutch Copyright Act, indicated by the "Taverne" license above, 


\section{Maastricht University}

Jaap Bos, Runliang Li,

Mark Sanders

Hazardous Lending: The Impact of Natural Disasters on Banks' Asset Portfolio

RM/18/021

\section{GSBE}

Maastricht University School of Business and Economics

Graduate School of Business and Economics

P.O Box 616

NL- 6200 MD Maastricht

The Netherlands 


\title{
Hazardous Lending: The Impact of Natural Disasters on Banks'
}

\author{
Asset Portfolio \\ Jaap Bos, Runliang Li, Mark Sanders*
}

August 23, 2018

\begin{abstract}
This paper studies how banks adjust their asset structure in response to changes in loan demand after natural disasters. We show how banks help clients smoothen consumption and support local recovery through their asset diversification strategy. In the empirical part, using a difference-in-difference method, we find that U.S. commercial banks increase real estate lending after disasters and sell government bonds to finance such a disasterdriven demand surge. In the theoretical part of this paper we present a novel multiple-asset dynamic credit rationing model that explains these empirical findings. Using simulations of our model we can then predict and quantify the possible impact of climate change on the asset structure and profitability of banks for different scenarios.
\end{abstract}

Keywords: banks, disasters, diversification, climate change

JEL: G21, Q54

\section{Introduction}

To understand the long-run impact of climate change on financial institutions, we can start by understanding how the latter react to recent natural disasters. This paper studies how banks adjust their asset structure in response to changes in loan demand after natural disasters such as extreme weather events. In light of progressing climate change this issue is highly relevant and likely to gain in relevance in years to come. To establish the empirical relevance of our study we

${ }^{*}$ Bos (corresponding author): Maastricht University School of Business and Economics, P.O. Box 616, 6200 MD, Maastricht, The Netherlands, j.bos@maastrichtuniversity.nl. Li: Institute for Economic and Social Research, Jinan University, 601 West Huangpu Road, Tianhe District, Guangzhou, China, lrjack@tju.edu.cn. Sanders: Utrecht University School of Economics, P.O. Box 80125, 3508 TC, Utrecht, The Netherlands, m.w.j.l.sanders@uu.nl. The usual disclaimer applies. Declaration of interest: none. 
first show that natural disasters affect the composition of loans and securities. We then present a dynamic credit rationing model to illustrate the most important underlying mechanisms and calibrate the model to reproduce our empirical findings. Using numerical simulations we can then investigate the potential impact of climate change on banks' balance sheets.

Since the most direct impact of natural disasters concerns banks' lending behavior, this paper fits well in the broader credit rationing literature. Credit rationing is a central topic of banking research. This literature firmly established that banks manage risks and credit portfolios more by rationing credit than by pricing strategies. ${ }^{1}$ If this behavior is observed under normal conditions, it is likely to also be observed after exogenous shocks to credit demand. A clear example of such an exogenous shock, would be an extreme weather event, such as a flood, hurricane or storm. This events destroy or damage property and thus create demand for credit to smooth consumption and rebuild productive assets. Against the background of climate change, extreme weather events are likely to become more frequent (Pachauri et al., 2014). Indeed, the impacts of climate change receive more attention from researchers, also in banking and finance. An emerging strand of literature discusses how banks geographically reallocate assets to meet disaster-driven increases in demand (Chavaz, 2014; Cortés and Strahan, 2017), how natural disasters affect banks' solvency (Klomp, 2014), and how bank-borrower relationships can affect borrowers' access to credit after natural disasters (Berg and Schrader, 2012; Koetter et al., 2016). With this paper we aim to contribute to this emerging literature.

To the best of our knowledge there are no studies investigating how banks may adjust the composition of their asset portfolio in response to natural hazards. A diversification strategy to manage natural hazards is important for banks as it follows standard practice in modern banking and is therefore easy to implement. Moreover, it provides banks with a powerful natural hedge against potentially large losses. By strategically (re)allocating assets between asset classes, banks can better serve the increased loan demand after disasters and thereby aid the recovery of economies hit by such events (Dlugosz et al., 2018).

To understand how banks diversify assets in response to (and anticipation of) natural hazards, we present both empirical evidence and a theoretical analysis to examine how natural hazards affect banks' asset allocations. For the empirical analysis we use the Call Reports that

\footnotetext{
${ }^{1}$ There is a long list of papers on bank's credit rationing. Theoretical papers include Stiglitz and Weiss (1981), Brunnermeier et al. (2012), and Gorton and He (2008). Empirical studies on the lending behavior include Hannan and Berger (1991), Angbazo (1997), Asea and Blomberg (1998), Carling and Lundberg (2005), and Zecchini and Ventura (2009).
} 
contain information of all U.S. commercial banks' balance sheet data over a period of 45 quarters from 2002 to 2013 and make use of two natural disaster datasets. The EM-DAT dataset that gives us detailed information about the time, location, type, magnitude, and damage of natural disasters. We then used the Federal Emergency Management Agency's records of major disaster declarations in the U.S. as a reference to check and complete the data in EM-DAT.

In our empirical section, we identify the causal effect of natural disasters on banks' asset allocation by applying a difference-in-difference (DID) analysis, estimating disasters' impact on asset quantities of commercial banks, choosing a \pm 1 year window. Using the 86 most costly natural disasters in the U.S. between 2001 and 2013, we find that the amounts of total loans and real estate loans significantly increased after these natural disasters, while banks' holdings of government bonds decreased. This result is robust to different lengths of the event window and consistent with previous findings. Firms and residents affected by natural disasters increase their demand for (mortgage) loans and banks react to this increase by supplying loans while selling government securities (Cortés, 2017).

In our theoretical section, we then develop a dynamic credit rationing model introducing multiple assets to also model the portfolio composition response. In our model, natural disasters destroy firms' and households' fixed capital, leading to a surge in the demand for loans and an increase in the borrowing rate. The impact of disasters on banks are then twofold. On the one hand, banks suffer delayed or defaulted loan payment as disasters destroy borrowers' capital and repayment capacity. On the other hand, banks have the opportunity to service the increased demand at higher interest rates, improving their margin and profitability.

We then calibrate our model to reproduce the key financial ratios we observe under normal conditions in our data and numerically simulate a negative disaster shock on firms' and households' capital in order to replicate our empirical findings. In the simulations, as in our data, we observe that banks increase post-disaster lending at higher interest rates, while selling government securities to finance these new loans. Of course, their ability to do so then depends on pre-disaster reserves and government security holdings. Both banks and society can thus benefit from more robustly funded banks. First, banks can satisfy the demand for loans from the public and thereby aid the recovery. Second, banks can increase their post-disaster revenue to compensate for the losses related to disaster-induced defaults.

Finally, we simulate scenarios of climate change to see how banks will respond and reallocate their assets. These simulations show that an increase in the (perceived) disaster probability due to climate change will be associated with decreased lending, a lower level of capital, less revenue 
and higher holdings of government bonds in the pre-disaster steady state. In other words, our model predicts that in normal times banks will keep a larger buffer of tradable government securities in anticipation of bigger and more frequent climate induced shocks in credit demand to benefit from "peak-shaving." Such behavior would be rational and socially optimal, but our simulations also show this reduces banks' income and returns-on-equity in normal times. Consequently such a long-run rational strategy may clash with the interests of short-sighted stock holders and a case for regulatory or supervisory interventions might be made.

Our paper thus makes three contributions. First, we empirically show that banks adjust their asset structure after natural disasters. In itself this is not new, but in this paper we analyze this in a setting with multiple assets and using state of the art empirical methods. Specifically, we show that banks issue more loans secured by real estate and sell government bonds to finance such increased lending. Second, we extend and generalize the Collier (2014) model to explain how this change in the asset structure is driven by a disaster-related credit demand shock. To model this, we introduce asset multiplicity and the credit demand side in the dynamic setting of Collier (2014), producing the interactions we observe. To our knowledge, this feature has not yet been introduced to the literature. Finally, our calibration and numerical simulation results help us quantify the potential impact of climate change on banks' balance sheets via the channel of natural hazards. To the best of our knowledge, that link has been proposed and hotly debated, but few have been able to provide sensible quantitative estimates of the impact.

The rest of this paper proceeds as follows. Section 2 positions our work in the relevant literatures to bring out these contributions more. Section 3 introduces our data and section 4 uncovers how natural disasters affect banks asset allocations. Section 5 presents our theoretical framework, calibrates the model, and compares model and data moments. Section 6 then simulates the impact of disaster shocks and climate change. Section 8 concludes.

\section{Positioning in the Literature}

Our paper is related to several strands of literature. At the macroeconomic level, our paper can be related to a handful of papers emphasizing the role of financial institutions in natural disaster alleviation and recovery. Toya and Skidmore (2007) report that countries with more complete financial systems suffer fewer economic losses after natural disasters. Noy (2009) corroborates that a higher level of domestic credit enhances a country's resilience to disaster shocks, but meanwhile points out that countries having less open capital accounts are more 
robust to natural disasters. Loayza et al. (2009) examine the impact of natural disasters on growth by disaster and industry type and assert that developing countries have more industrial sectors affected than developed countries. The present paper goes beyond this literature by zooming in on the responses of individual banks to natural disasters.

Concerning the micro-level behavior that explains the above phenomena, our paper can be related also to the recent literature of credit dynamics during natural disaster times (Berg and Schrader, 2012; Chavaz, 2014; Koetter et al., 2016; Cortés and Strahan, 2017; Dlugosz et al., 2018). For example, Berg and Schrader (2012) show that the demand for credit increases after volcanic eruptions in Ecuador and find that bank-firm relationships positively predict firms' post-disaster access to credit. Focusing on the supply side, Chavaz (2014) shows that local banks of disaster-struck regions possess more private information of borrowers than geographically diversified banks. During the 2005 U.S. hurricane season, local banks, through loan sales, could circumvent capital constraints and satisfy firms' increased mortgage demands. Cortés and Strahan (2017) find that banks geographically reallocate funds when local credit demand increases after natural disasters. Moreover, they find banks increase sales of more-liquid loans to lessen the impact of the demand shock on credit supply. In this paper, rather than focusing on the geographic distributions of assets, we propose that reallocation of resources within a bank can also smooth its income and is beneficial to banks and the local community.

This emerging literature typically builds on models that were developed in the literature on credit rationing. Allocating assets among customers of mixed types with various demands is the bread-and-butter business of commercial banks. And indeed, the provision of credit is so central to the health of the economy and the welfare of households that a large body of research has been devoted to understanding banks' lending behavior. At the micro level, the formation of equilibrium contract rates and the resultant asset composition determine both banks' profitability and firms' productivity. For example, the contraction of real estate loans after the sub-mortgage crisis by most commercial banks dampened the real estate industry, whereas banks' supporting of loans after natural disasters with the assistance of governmental agencies can accelerate recovery speeds. From the macro perspective, credit rationing is one of the major sources of financial frictions that may significantly affect the effectiveness of fiscal and monetary policies. ${ }^{2}$

\footnotetext{
${ }^{2}$ Theories of optimal portfolio choice can be dated back to Markowitz (1952), Merton (1969), and Samuelson (1969). Theoretical microeconomic models to the optimal credit rationing literature are discussed in papers by Porter (1962), Jaffee and Modigliani (1969), Klein (1970, 1971), Broaddus (1972), Pringle (1974), Sealey (1980),
} 
Still, most of the existing models consider the dynamics of a single aggregated asset rather than the intertemporal interaction among multiple assets. Our paper is related to this literature as we model the behavior of banks over time in response to exogenous shocks in a dynamic, multiple asset setting. ${ }^{3}$ The need to study the dynamics of multiple assets stems from fact that banks change not only the volume of loans but also the composition of their portfolio of assets. The theoretical model in our paper is closely related to Collier (2014) who sets up a dynamic lending model and evaluates the impact of disaster-related credit risk on the loan supply to small enterprises. The model predicts that lenders suffer losses in their income and therefore contract credit after big natural disasters, which is supported by data of a small business lender in Peru after the severe El Niño-related flooding of 1998. Instead of focusing on the payment shock, our paper incorporates the demand side of loans, i.e. the production sector, and examines the demand shock that follows natural disasters. In fact, the payment shock is caused by the disaster shock to firms' capital. By linking the payment shock and demand shock together, our model becomes more general and helps us understand the behavior of both the demand and supply sides.

Therefore we explicitly model both. The demand side includes responses of households, government, and firms of varied industries. For firms especially, the demand for loans relies greatly on their life cycle stage and on the region's comparative advantages. On the supply side, banks categorize their assets into cash, securities, and loans (e.g., real estate, commercial and industrial, and household loans), and each category is subject to various regulatory requirements.

Finally, we can relate this paper to the emerging literature on increasingly frequent and more catastrophic climate related natural disasters. ${ }^{4}$

Stiglitz and Weiss (1981), and Slovin and Sushka (1983). Works in macroeconomics in understanding the roles of financial intermediaries include papers by Pagano (1993), Bernanke and Gertler (1989), Carlstrom and Fuerst (1997), Iacoviello (2005), and Brunnermeier et al. (2012). Gorton and He (2008) model and test bank credit cycles in the repeated game framework. For empirical studies of the lending behavior, see Hannan and Berger (1991), Angbazo (1997), Asea and Blomberg (1998), Carling and Lundberg (2005), and Zecchini and Ventura (2009).

${ }^{3}$ An early contribution that considers the intertemporal relationships among multiple categories of banks' balance sheets is the paper by Broaddus (1972). Recent studies that incorporate large exogenous shocks are papers by Chavaz (2014) and Collier (2014).

${ }^{4}$ See, for instance, Rietz (1988), Barro (2006, 2009, 2015), Gabaix (2008), Gourio (2012), and Wachter (2013) who study rare economic disasters. Papers by Allen and Gale (2000), Acemoglu et al. (2015), and Sun (2016) have made helpful progress in exploiting systematic and endogenous shocks. 
In conclusion, our contribution in this paper is to develop a multi-asset dynamic credit rationing model that we use to make sense of the data and may simulate to assess the potential impact of climate induced natural hazards on bank balance sheets and credit supply.

\section{$3 \quad$ Data and Descriptive Statistics}

To establish the stylized facts we are primarily interested in in this paper, we collect data on individual banks' balance sheet composition, the market prices for these asset categories and data to identify which banks were in a region that was affected by a natural disaster. The banks' balance sheet items are from banks' Call Reports, and the disaster records are from EMDAT (Guha-Sapir et al., 2015) and FEMA. We also collect the state-average interest rates from Uniform Bank Performance Reports (UBPRs). In the next two subsections, we first discuss our data collection procedure and then present descriptive statistics.

\subsection{Data Collection}

\subsubsection{Balance Sheet Variables}

We collect data on loans, securities, deposits, and equity are from the Call Reports of all federally insured commercial banks in the United States. Our sample covers 45 quarters from 2002:Q4 to 2013:Q4 and includes 356,452 bank-level observations in total. From this source we extract and compile loans secured by real estate, commercial and industrial loans, consumer loans, federal government securities, total loans, total assets, and total equity. ${ }^{5}$

\subsubsection{Interest Rates}

The rates of returns on assets are not in the Call Reports but are recorded in the Uniform Bank Performance Report (UBPR). The UBPRs collect variables at the state-level, so the rates are the state averages. For example, UBPRs define the yield on real estate loans as the "interest and fees on domestic office loans secured primarily by real estate, divided by average domestic real estate loans." In addition to interest rates, we obtain from the UBPRs the net loan loss

\footnotetext{
${ }^{5}$ The federal government securities include the U.S. Treasury securities and the U.S. Government agency obligations. When we refer to "government security" or "government bond", we mean the sum of these two items. We do not, however, include the "local government securities" which are securities issued by states and political subdivisions in the U.S. because these two types of securities have different interest rates according to the Chapter "Noninterest Income, Expenses and Yields" of the UBPR.
} 
rates that are used to calibrate the non-repayment rates in the model. As individual bank interest rates do not deviate from the state average, we model banks as price takers, so we can assume interest rates for individual banks are more or less equal for all banks in a state. Arbitrage ensures that interest rates are also highly correlated across bank asset types. We plot the development of interest rates in Figure 7 in the Appendix. The Figure shows high correlations among all types of assets and demonstrates that all interest rates indeed move almost in parallel. It is thus reasonable for us to model the interest rate to be the sum of a common prime lending rate determined by the production sector and a risk premium for specific asset types.

\subsubsection{Disasters}

We gather disaster data from two sources. Our first data source is the EM-DAT, a comprehensive dataset of disaster characteristics. The dataset includes the worldwide natural disasters of all types and records the dates, human death toll, material damages, and geographic locations of the disasters. We extract disasters in the U.S. from 2001 to 2013 and selected disasters whose costs are in the top 5\%, leaving to 86 disasters for the analysis. ${ }^{6}$ We match the location of each disaster with counties and classified counties into treatment and control groups in the difference-in-difference (DID) analysis presented below.

We also looked at the disaster declaration records from the Federal Emergency Management Agency (FEMA) between 2000 and 2015. Each declaration item contains four variables: the date, the state, the type of the disaster, and the declaration type. The types are not recorded in a uniform manner. For instance, fires are often recorded together with the name of their locations; hurricanes and tropical storms are used interchangeably; and floods are sometimes recorded alone but occasionally recorded with other disasters such as winter storms or severe storms. As the FEMA data are not as detailed and well-sorted as the EM-DAT data, we only used them as a reference and to calculate the disaster probability for each state.

\footnotetext{
${ }^{6}$ The EM-DAT contains a lot of non-disasters, where damages and human impacts are very mild and would not be considered a disaster. As it is not likely such non-events have significant impacts on local financial markets, we chose to focus on the top $5 \%$. Our results are thus representative for the more extreme events only.
} 


\subsection{Descriptive Figures and Statistics}

\subsubsection{Bank Variables}

To give an overall impression of our sample, we show summary statistics for the major bank variables in Table 1. The Table includes the mean, standard deviation, $10^{\text {th }}$ and $90^{\text {th }}$ percentile values at the bank-quarter level. To account for the effect of bank size, we divide banks into small banks (Panel A) and large banks (Panel B) according to their total assets. The large standard deviations in both panels indicate that the samples include heterogeneous banks across the country. Furthermore, the statistics reveal that loans secured by real estate account for nearly 50 percent of the total assets. Since this type of loan is secured by real estate, it is considered safer compared to other types of loans, which have either other kinds of collateral or no collateral at all. ${ }^{7}$ Interestingly, small and large banks have rather similar real estate lending ratios, and in general a fairly similar asset composition.

\subsubsection{Disaster Frequency}

By examining disaster records in both the EM-DAT and FEMA datasets, we find that, first, natural disasters are very prevalent in the U.S.. There are, however, regional differences. In the western territory, wildfires are the biggest natural threat, while in the gulf coast region, floods and tropical storms are the most frequent hazards. Second, the costs of natural disasters are highly skewed. As shown in the EM-DAT dataset, among the 1707 recored natural disasters in the U.S. during 2001 and 2013, disasters that cause more than $\$ 1$ billion in losses account for only 3.51 percent, while zero-cost disasters are about 85.47 percent. Among these zero-cost events, around $30.71 \%$ are wildfires and $20.08 \%$ are tornados. Among the top 5 percent most costly disasters, around $90 \%$ are floods and hurricanes. Given that these disasters are prevalent and they can affect a large area, we choose a radius of $200 \mathrm{~km}$ to identify the affected counties in our empirical analysis; this relatively large radius yields on average 50 affected counties in a top $5 \%$ disaster.

To give a further impression about the type and frequency of disasters, we plot the following figures based the FEMA disaster records. Figure 1 counts the number of declared "major disasters" based on FEMA records from 2000 to 2015. The Figure indicates that the most prevalent countrywide natural disaster is floods, whereas wildfires are the most common natural disaster in states like Texas, California, and Wyoming.

\footnotetext{
${ }^{7}$ For a more detailed explanation on the role of collateral, see Gan (2007) and Chaney et al. (2012).
} 


\section{Table 1: Key Statistics}

This table displays statistics for variables using Call Reports data that cover all commercial banks in the United States. All the variables are in millions of dollars. The mean, standard deviation, $10^{\text {th }}$ percentile, and $90^{\text {th }}$ percentile are based on individual bank-quarter observations. To account for the effect of bank size, we group banks into small bank (Panel A) and large bank (Panel B) groups according to their total assets. The medium of total assets is around \$0.1 billion. Banks with total assets less than $\$ 0.1$ billion are classified as small banks whereas banks having assets between $\$ 0.1$ and $\$ 9$ billion are large banks. We choose $\$ 9$ billion as the upper limit because it is already beyond the $99.5^{\text {th }}$ percentile and the remaining values are treated as outliers.

\begin{tabular}{|c|c|c|c|c|c|}
\hline & & Standard & $10^{\text {th }}$ & $90^{\text {th }}$ & \\
\hline & Average & Deviation & Percentile & Percentile & Observations \\
\hline \multicolumn{6}{|c|}{ Panel A: Small Banks ( $<\$ 100$ million in assets) } \\
\hline Total Assets & 53.900 & 24.952 & 20.727 & 89.388 & 130908 \\
\hline Total Loan & 32.814 & 19.114 & 9.449 & 60.563 & 130908 \\
\hline Real Estate Loan & 21.047 & 15.383 & 4.043 & 43.424 & 130908 \\
\hline C\&I Loan & 5.025 & 4.982 & 0.745 & 11.027 & 130908 \\
\hline Individual Loan & 2.821 & 2.985 & 0.425 & 6.135 & 130908 \\
\hline Government Securities & 5.236 & 6.476 & 0 & 13.516 & 130908 \\
\hline Total Equity & 6.389 & 4.000 & 2.352 & 10.691 & 130908 \\
\hline Deposit & 37.569 & 18.555 & 13.422 & 63.323 & 130908 \\
\hline \multicolumn{6}{|c|}{ Panel B: Large Banks (\$100-9000 million) } \\
\hline Total Assets & 642.871 & 2666.346 & 116.679 & 991.604 & 177861 \\
\hline Total Loan & 422.952 & 1860.527 & 70.209 & 669.344 & 177861 \\
\hline Real Estate Loan & 287.145 & 1044.587 & 42.972 & 495.646 & 177861 \\
\hline C\&I Loan & 63.493 & 345.393 & 5.319 & 102.488 & 177861 \\
\hline Individual Loan & 51.401 & 1050.935 & 1.110 & 32.859 & 177861 \\
\hline Government Securities & 31.362 & 187.644 & 0 & 59.419 & 177861 \\
\hline Total Equity & 68.837 & 361.937 & 11.114 & 99.477 & 177861 \\
\hline Deposit & 395.771 & 1415.997 & 80.275 & 651.487 & 177861 \\
\hline
\end{tabular}




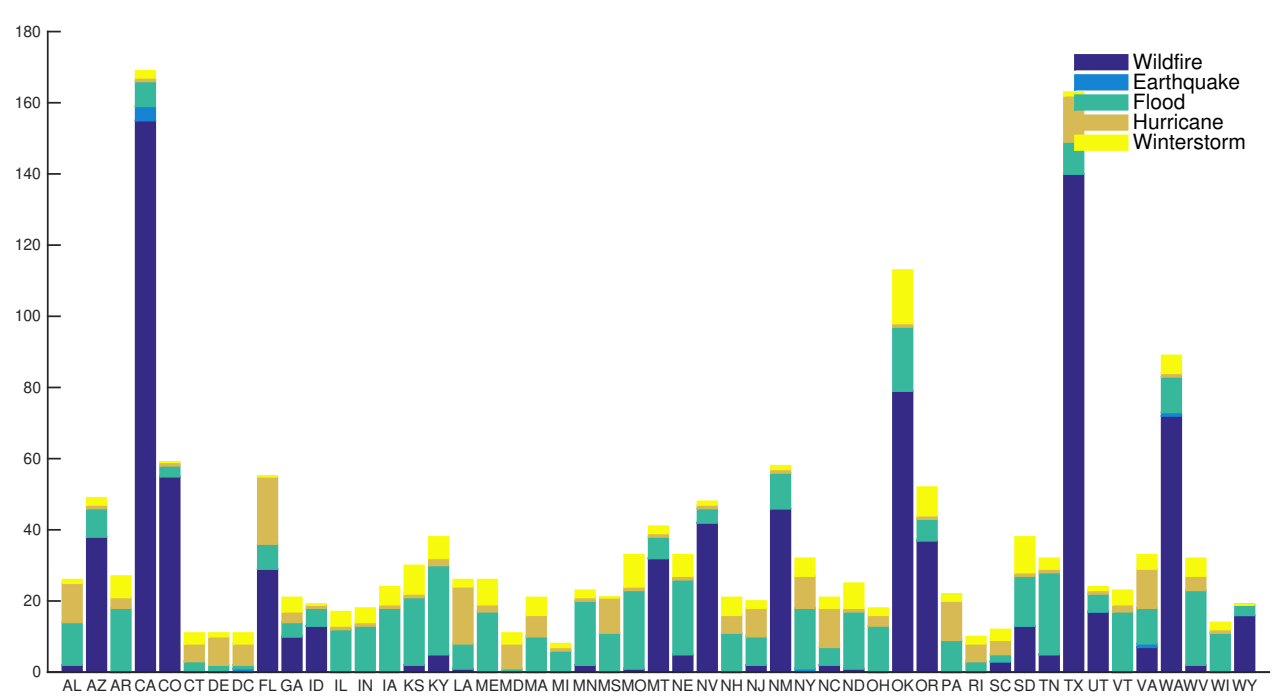

Figure 1: Counts of Natural Disaster Declarations (2000 to 2015). This figure displays the frequencies of each one type of the five disasters for every state. The data includes disaster declarations available on the website of the Federal Emergency Management Agency (FEMA).

In addition, based on the major disaster declarations, we calculated a quarterly probability of natural disasters for each state. For example, Louisiana has declared 20 major disasters between 2000 and 2015, and therefore the average quarterly frequency of natural disasters is $20 /(16 \times 4)=31.25 \%$. Figure 2 plots the histogram of disaster counts. Based on this graph, we calculate the average quarterly disaster probability for each state to be about $22.85 \%$. This value will be used as the bank's subjective perception of the disaster probability when we calibrate the model. ${ }^{8}$

\section{Empirical Analysis}

In this section, we show how banks react to disaster-driven demand shocks. Consistent with Cortés (2017), we find that natural disasters lead banks to increase the amount of loans secured by real estate and decrease holdings of government bonds. We also look at other types of assets such as commercial and industrial loans, consumer loans, and total loans. We show decreases in the amount of commercial loans, while consumer loans increase. Overall, the amount of

\footnotetext{
${ }^{8}$ Knowing the exact value of bank's subjective disaster probability is impossible. We follow the common practice in the disaster and business cycle literature by calculating the probability based on realized disasters (Barro, 2006; Gabaix, 2008; Barro, 2009; Gourio, 2012; Wachter, 2013; Barro, 2015).
} 


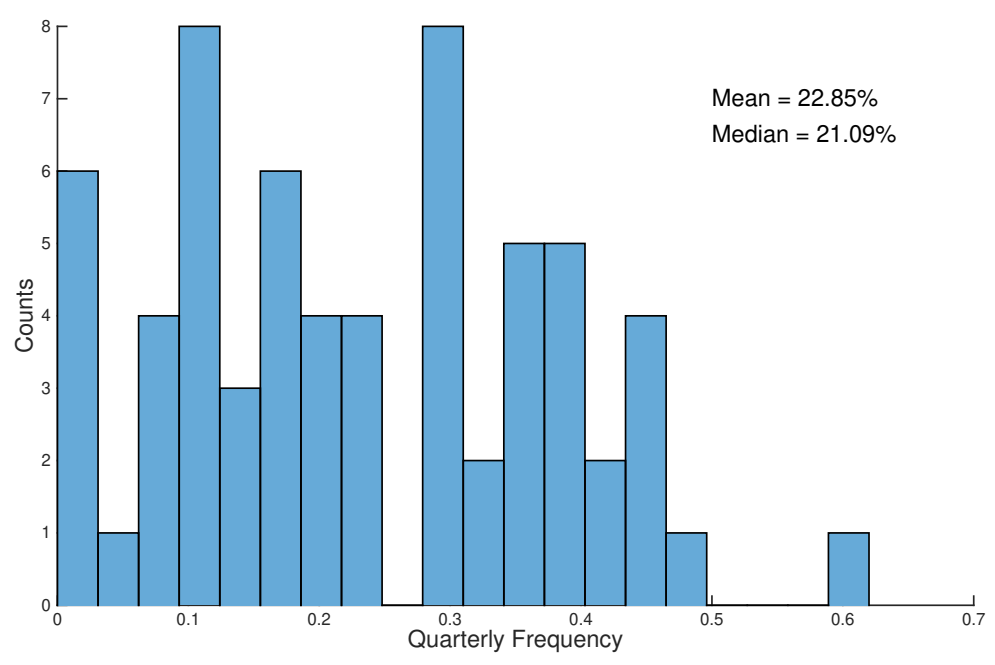

Figure 2: Distribution of Quarterly Frequency of Major Disasters. This figure exhibits the histogram of quarterly average frequencies of "major disasters" across different states and territories of the U.S.. The data comes from the FEMA. Based on this histogram, we calculate the average disaster frequency to be $22.85 \%$. This value will be used in our model as the bank's perceived disaster probability to calibrate the model.

total loans increases after natural disasters. In our baseline analysis, we choose a \pm 1 year event window. We tested for other event windows for robustness and results are shown in the Internet Appendix.

\subsection{Identification and Methodology}

To identify a causal effect of natural disasters on banks' balance sheets, we rely on a differencein-difference (DID) analysis. That is, we identify the impact of a disaster by looking at the difference between affected and non-affected banks in the change of balance sheet composition over time. The implicit assumption is that all banks change their balance sheet in a similar way in response to any common shocks over time. The impact of a disaster is then (on average) equal to the (average) difference in this change. Our identification strategy relies on being able to identify banks in our dataset that have and have not been affected by an event of known location and intensity.

Closer inspection of our disaster data reveals that it contains a lot of events that one would generally not consider disasters. To prevent these non-events from biasing and obscuring the results we are interested in, we selected, admittedly somewhat arbitrarily, the most costly $5 \%$ recorded disasters in our EM-DAT data set. At that cut-off level we are left with 86 events affecting multiple counties in the 11 years (or 45 quarters) that our dataset spans. We 
choose these large-scale disasters to make sure that these disasters are ex-ante unpredictable and exogenous. Arguably, firms and banks already have subjective beliefs about the risks in their region and are therefore to some extent prepared for the more mundane events. In addition, only relatively big disasters generate a significant and regionally correlated shock affecting productive and residential capital of nearly all local firms and residents at the same time. Consequently, only relatively large events can reasonably be assumed to cause significant loan defaults, an increase in credit demand, and to drive up borrowing costs.

HERE Next, we need to distinguish between those banks that have been affected by a disaster and those that have not been affected. We know the county in which a bank (or its branch) is located as well as the county in which a disaster takes place. For each disaster, we first create a group of "affected" and "unaffected" counties. We define a county to be affected by a natural disaster if this county is located within a $200 \mathrm{~km}$ radius of the recorded disaster center. Since the actual impact of the disaster also depends on the shape of the flood plane, path of a hurricane and area of wildfires - on which we lack information - this is likely to introduce some noise in our measures. This noise, however, will mainly result in labelling as affected areas that did not suffer damages, in which case the coefficients in the DID will be biased towards zero. As a result, our DID tests are rather conservative.

Our control group of unaffected needs to be as similar as possible to the affected counties, but without the impact of the disaster. We therefore define as unaffected counties located between $300 \mathrm{~km}$ and $400 \mathrm{~km}$ radius of the disaster center. Again, in this group we may include affected counties in for example the path of a hurricane or storm (floods rarely extend beyond $200 \mathrm{~km}$ and wildfires never do). For our DID-analysis we thus ignore the banks in counties in the $200-300 \mathrm{~km}$ ring because it is ambiguous if they are affected or not, whereas we also ignore those more than $500 \mathrm{~km}$ removed from the disaster center, as these are less likely to experience similar non-disaster related shocks. This grouping method leads to the number of affected and unaffected counties to be around 50 each per event in our dataset. For each event, the banks in the approximately 50 affected counties are then compared to the banks in the approximately 50 unaffected counties.

We then examine the average effect of all the selected events using the following empirical model:

$$
y_{b c t}=\beta_{0}+\beta_{1} \text { Affected } \text { f }_{c} \times \text { PostDate }_{t}+\gamma X_{b c t}+\text { CountyFE }+ \text { TimeFE }+\epsilon_{b c t},
$$

where $y_{b c t}$ represents the quantity of an asset of bank $b$ located in county $c$ at quarter-year $t$. 
Af fected equals 1 if a county is affected, and 0 otherwise. PostDate equals 1 if the observation date $t$ is after the end date of the event recorded in the EM-DAT. The county fixed effects and time fixed effects capture unobservable regional traits and macroeconomic conditions that may confound with disaster-driven demand shocks. In line with Koetter et al. (2016), we control in $X_{b c t}$ for bank-specific variables including bank size (total assets), capital adequacy (total equity/total assets) and liquidity (non interest bearing cash/total assets).

\subsection{Results of DID}

We present the baseline results of our DID analysis in Table 2. We divided banks into small and large banks to reduce the possible distortion effect of bank size. In the current baseline results, we use a \pm 1 year event window centered on the date of the disaster. We thus compare the average bank located within a $200 \mathrm{~km}$ radius of the reported centre of the event to an average bank located between 300 and $400 \mathrm{~km}$ from that same point.

Our results show affected banks increase real estate lending and decrease holdings of government securities after disasters, which is consistent with Cortés (2017). The coefficients are both statistically and economically significant. For example, small banks in the affected counties on average increase real estate lending by $\$ 0.961$ million more than those in unaffected counties. Given the average amount of real estate loans of $\$ 21.047$ million, as shown in Table 1, this is a $4.6 \%$ increase. Meanwhile, large banks increase their real estate loans by $\$ 2.71$ million, which is a $1 \%$ increase compared to the average amount. This is less, but given larger volumes, still very significant. As for government bonds, small and large banks decrease their holdings by $\$ 0.227$ and $\$ 1.025$ million respectively, corresponding to a $4.3 \%$ and $3.3 \%$ decrease from the average level. In a recent study by Schüwer et al. (2018), using Hurricane Katrina as a natural experiment, the authors also found significant decreases in government bond holdings of affected banks.

In addition, we find that banks increase their credit supply to households and individuals (i.e. consumer loans) and decrease lending to the commercial and industrial sector. In the \pm 1 year event window setting, these results are not statistically significant. However, when we increase the event window to \pm 3 years, as show in Table 3 , we find significant coefficients for both types of loans, especially for small banks and the results for real estate loans, government securities, and total loans remain robust.

Finally, the net effect turns out to be an increase in total loans. The net increase is smaller than the increase in real estate loans, however, due to the decrease in commercial lending. Our 


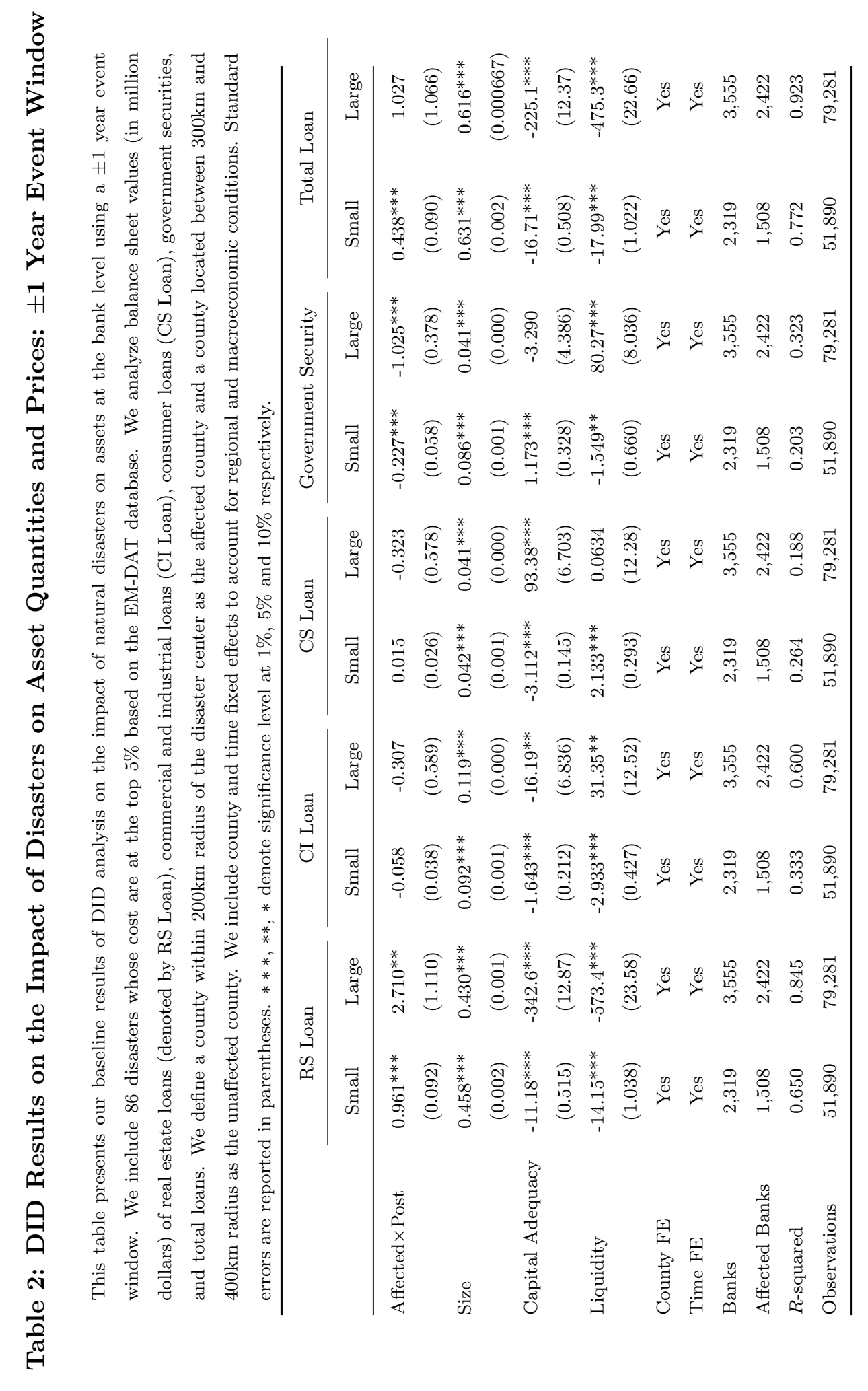




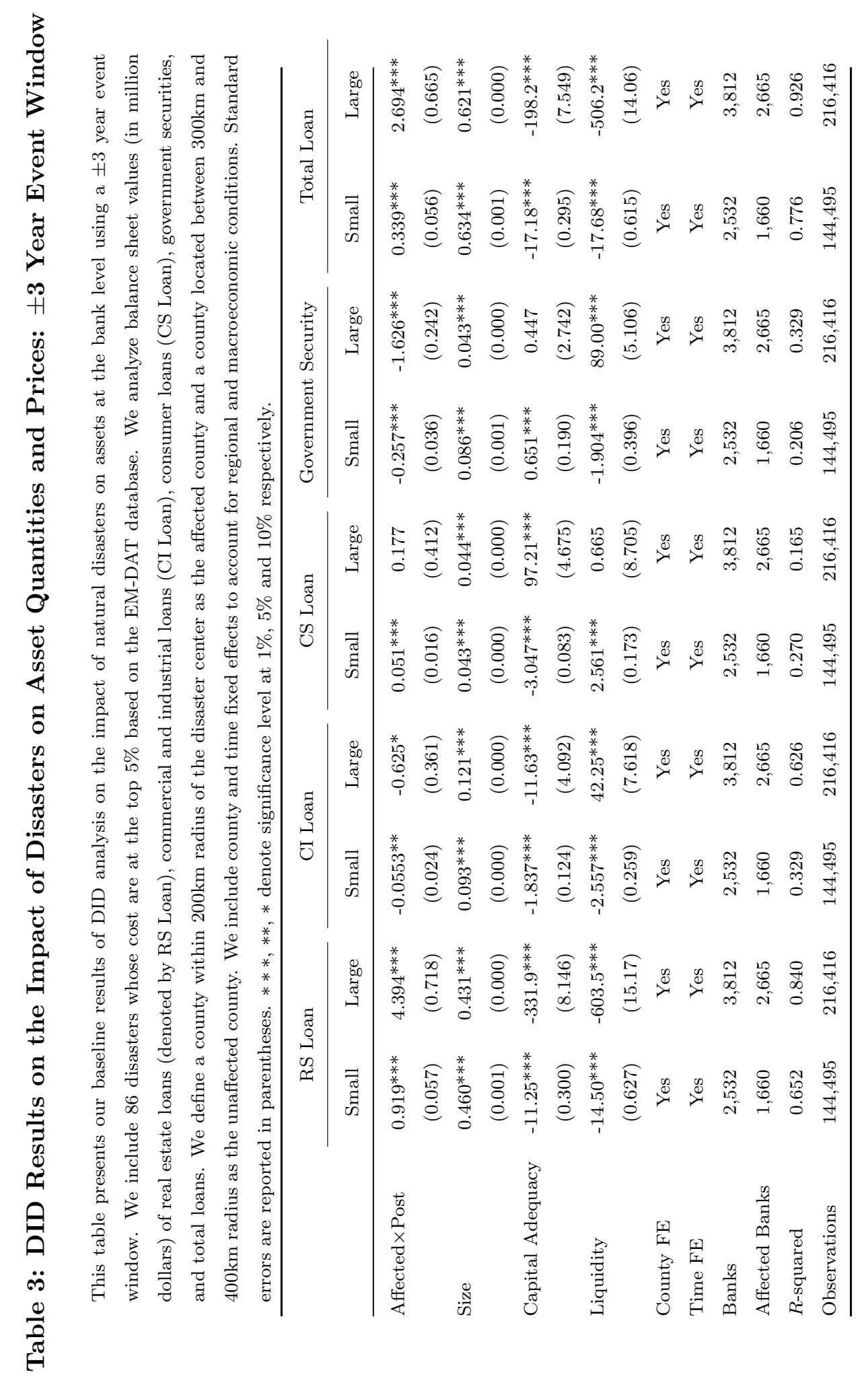


findings indicate that big natural hazards have long-term impact on bank asset structure, and small banks are more sensitive to adverse events than large banks, possibly because they are geographically less diversified than large banks Cortés and Strahan (2017). ${ }^{9}$

In the next section, we provide a theoretical model to explain our two main empirical findings. First, our model captures the fact that disasters stimulate communities' demand for loans for reconstruction by destroying capital. Therefore, banks extend credit and meanwhile sell government bonds to finance such a increase in demand. Second, by assuming that disasters lead to more defaults of commercial loans than real estate and consumer loans, our model explains why real estate lending increases yet commercial lending decreases after natural disasters.

\section{$5 \quad$ Theoretical Model}

In this section, we first set up a theoretical model to explain banks' asset allocation behavior during disastrous times. Next we calibrate the parameters of the model and compare key financial ratios implied by the model with real data. This comparison shows that our model is able to reproduce the data reasonably well and sets the stage for the simulation of a natural disaster and climate change scenarios in the next sections.

We begin with a single asset model to introduce our main variables and show how banks make lending decisions based on loan conditions, disaster probability, and interest rate (model 1). Next, we allow for multiple assets, which enables us to generate interactions among assets when a disaster strikes (model 2). Our model contains two economic agents: banks and firms, that represent the supply and demand side of funds, respectively. Collectively, firms have an infinite demand at a market borrowing interest rate that is determined by the marginal productivity of capital in production and investment. Individual banks then decide how much to lend, based on this interest rate. A disaster is modeled to destroy firms' capital, increasing the marginal productivity of capital, the borrowing interest rate, and possibly the non-repayment rates of existing loans. Individual banks are assumed to aim at maximizing shareholder value and endogenously react to this shock by adjusting their asset structure. The single asset banking model is mainly based on the model of Collier (2014). In the next subsections we first present their basic setup, then add the production sector in the one-asset model and finally extend this to a multi-asset setting.

\footnotetext{
${ }^{9}$ We try different event windows in the Internet Appendix. As we extend the event window, the negative coefficient on commercial loans and positive coefficient on consumer loans become more significant.
} 


\section{$5.1 \quad$ Basic Model Setup}

Following Collier (2014) we introduce a risk-neutral bank that maximizes its shareholder value over an infinite horizon. Every period, the bank generates new aggregated loans $L_{t}$, but only a fraction, $\tilde{L}_{t}$, are paid back at the end of the period due to default. ${ }^{10}$ We model such a relationship as:

$$
\tilde{L}_{t}=\left(1-\xi_{t}\right) L_{t}
$$

where $\xi_{t}$ is the non-repayment rate that is affected by various types of shocks, including natural disasters. It is specified as:

$$
\xi_{t}=\bar{\xi}+\epsilon_{t}^{\xi}
$$

where $\epsilon_{t}^{\xi}$ captures unexpected shocks and $\bar{\xi}$ represents the bank's expected non-repayment rate:

$$
\bar{\xi}=p\left(\mu+\xi^{*}\right)+(1-p) \mu=\mu+p \xi^{*},
$$

where $\mu$ represents the non-repayment rate in normal times, $\xi^{*}$ is the average non-repayment rate increment when a disaster happens, and the bank expects the disaster to happen $\left(x_{t}=1\right)$ with a probability $p$. We introduce this probability here to simulate different scenarios of climate change using different values of disaster probability $p$ in the sections below. For now, it suffices to note that a higher disaster probability implies a higher expected non-repayment rate.

The net income, $R_{t}$, is the interest income of performing loans, $r_{t} \tilde{L}_{t}$ less the deposit interest payment, $r_{t}^{D} D_{t}$, the origination costs for new loans $h\left(l_{t}\right)$, and the loan losses $\xi_{t} L_{t}$, yielding:

$$
R_{t}=r_{t} \tilde{L}_{t}-r_{t}^{D} D_{t}-h\left(L_{t}\right)-\xi_{t} L_{t}
$$

where $r_{t}$ and $r_{t}^{D}$ are the interest rates on loans and deposits respectively. We specify $r_{t}$ as:

$$
r_{t}=r_{t}^{*}+\kappa
$$

with $r_{t}^{*}$ is the equilibrium basic lending rate determined on the production side, introduced below and $\kappa$ is the risk premium of the loan. In Collier (2014)'s model, the basic borrowing/lending interest rate $r_{t}$ is a given parameter. In our model, however, we let it to be determined by the

\footnotetext{
${ }^{10}$ Since $L_{t}$ is the stock variable, it would be more precise to include a motion equation, $L_{t+1}=L_{t}+l_{t}$, where $l_{t}$ is the newly issued loans, a flow variable. The latter then represents a choice variable, as banks determine how many new loans they issue every period. However, it is in fact equivalent to assume that the bank decides on total outstanding loans $L_{t}$ every period. The model will produce exactly the same result whether we specify the motion equation or not. More importantly, since our empirical analysis tests the stock, not flow, of loans, letting the bank decide the level of $L_{t}$ makes the theory consistent with the empirical analysis.
} 
production sector to introduce a second channel through which natural disasters can enter the banks' decision making. By destroying capital, natural disasters increase loan demand as well as the interest rate. Banks then make decisions based on the changed conditions of the economy. This improvement makes our mechanism more elaborate and realistic. ${ }^{11}$ We can relate deposit $D_{t}$ to the interest rate $r_{t}^{D}$ and a constant $N$ that controls the size of the balance sheet: ${ }^{12}$

$$
D_{t}=N\left(1+r_{t}^{D}\right)
$$

Consequently, the total loans that the bank can generate is constrained by the balance sheet identity:

$$
L_{t}=D_{t}+E_{t}
$$

As a bank generates more loans, it faces origination costs associated with searching, evaluating, and monitoring borrowers as well as more severe regulation on leverage from authorities. A convenient cost function to reflect that process is:

$$
h\left(L_{t}\right)=\eta L_{t}+\frac{\psi}{2} L_{t}^{2},
$$

where the linear component implies that origination costs are proportional to the amount of loans, whereas the quadratic part captures the fact that for a bank that already has issued a lot of loans, it becomes more difficult to search, evaluate, and monitor new borrowers and meets increasingly invasive interventions from the banking authorities when its leverage becomes too high. ${ }^{13}$ The next period's equity is the current equity less dividend payments plus income:

$$
E_{t+1}=(1-\nu) E_{t}+R_{t}
$$

\footnotetext{
${ }^{11}$ From an empiricist's point of view, the interest rate is persistent. Especially for loans, both banks and customers can not change the rate whenever they want, so the interest rate in the next period is highly correlated with the rate of the last period. This calls for a more realistic interest rate process, for example, $r_{t}=\rho r_{t-1}+$ $(1-\rho) \bar{r}_{t}+\epsilon_{t}^{r}$, where $\rho$ represents the persistence of the interest rate and $\epsilon_{t} \sim N\left(0, \sigma^{2}\right)$ is a random shock. In the later simulation part, to conform to reality and also to improve the readability of graphs, we set $\rho>0$, which means banks continue to charge a higher interest rate some quarters after the disaster. To keep the exposition of the model clean, however, we set $\rho=0$ here.

${ }^{12}$ This is also an extension compared to Collier (2014)'s model that simply set deposits to be the difference between asset and equity. In this way, we can add a shock to the deposits when we have reasons to believe that households and banks react to disasters by withdrawing deposits or changing the deposit rate. We will not dwell on this experiment here, however, for two reasons. First, we want to focus on the topic of banks' asset allocation rather than how banks adjust their deposit rate.Dlugosz et al. (2018) study in detail how banks' decision-making delegation affects their ability to set deposit rate and the consequence of deposit level and economic recovery. Second, we did not find robustly significant empirical evidence on the change of deposit after disasters.

${ }^{13}$ In Collier (2014), the author explicitly models the regulation cost as a step function that stays at zero when the leverage is low and increases when the leverage exceeds the regulation threshold. We smooth this process in
} 
where $\nu$ is the dividend rate. Finally, the bank's problem is maximizing its overall dividend payment discounted by a time discount factor $\gamma$ :

$$
\max _{L_{t}} \Pi_{0}=\sum_{t=0}^{\infty} \gamma^{t} \mathbb{E}\left[\nu E_{t}\right], \quad 0<\gamma<1
$$

To complete the model, we need to introduce the demand side for loans, that is the production sector. We assume a mass of price-taking banks and firms, such that the demand for a single bank's loans is infinite at the market-determined interest rate and this rate must be equal to firms' marginal productivity of capital.

\subsection{Introducing Firms}

As a disaster affects the whole economy in an affected location, we should consider both the financial and non-financial sectors. We will let firms as a whole to determine the basic borrowing interest rate through production and investment; individual banks then decide how much to lend based on the given interest rate. We model firms based on a business cycle model of Gourio (2012); they produce output using a Cobb-Douglas production function:

$$
Y_{t}=A K_{t}^{\alpha}
$$

where $A$ is productivity level, also known as the total factor productivity (TFP). Capital is accumulated according to the law of motion for production capital:

$$
K_{t+1}=\left(1-\delta_{t}\right) K_{t}+\phi\left(\frac{I_{t}}{K_{t}}\right) K_{t}
$$

where $\delta_{t}$ is depreciation rate, $I_{t}$ is the demand for funds, and $\phi\left(\frac{I_{t}}{K_{t}}\right)$ is a function describing capital adjustment costs. ${ }^{14}$ A disaster can now be introduced into the model as a sudden increase in the capital depreciation rate:

$$
\delta_{t}=\bar{\delta}+\epsilon_{t}^{\delta}
$$

If $\epsilon_{t}^{\delta}$ and $\epsilon_{t}^{\xi}$ are positively correlated, then this means disasters indeed lead to defaults of existing loans. Finally, firms maximize profit over time according to:

$$
\max _{I_{t}, K_{t+1}} \Pi_{0}^{\text {Firm }}=\sum_{t=0}^{\infty} \beta^{t} \mathbb{E}\left[Y_{t}-I_{t}-r_{t}^{*} K_{t}\right], \quad 0<\beta<1,
$$

this specification as the kinked function complicates the numerical computations below and is not important to our model's main mechanism.

${ }^{14}$ Here we follow the convention of business cycle literature and specify the capital adjustment function to be $\phi\left(\frac{I_{t}}{K_{t}}\right)=\frac{I_{t}}{K_{t}}-\frac{\iota}{2}\left(\frac{I_{t}}{K_{t}}-\delta\right)^{2}$. It is therefore an increasing and concave function. 
where $\beta$ is the time discount factor for firms. Through their production and investment decisions, firms collectively determine the basic borrowing interest rate:

$$
1+r_{t}^{*}=\phi^{\prime}\left(\frac{I_{t}}{K_{t}}\right)\left(\frac{1-\delta_{t}+\phi\left(\frac{I_{t+1}}{K_{t+1}}\right)}{\phi^{\prime}\left(\frac{I_{t+1}}{K_{t+1}}\right)}+\alpha \frac{Y_{t+1}}{K_{t+1}}-\frac{I_{t+1}}{K_{t+1}}\right) .
$$

Equation (16) shows that if disasters increase the depreciation rate of firm capital, this endogenously drives up the interest rate and by assumption affects the non-repayment rate, such that they eventually lead banks to adjust their capital structure. The model, however, still cannot explain the interactions among different asset types after disasters. For this, we need to make a further extension to incorporate multiple assets.

\subsection{Bank with Multiple Assets}

Having established the single-asset model, we can slightly enrich the model to allow for interactions among multiple assets. ${ }^{15}$ Note that each asset now has its own non-repayment rate (zero for government bonds), interest rate and cost function. The net income then includes the sum of interest income of all assets:

$$
R_{t}=\sum_{i=1}^{n} r_{i t} \tilde{L}_{i t}-r_{t}^{D} D-h\left(L_{t}\right)-\sum_{i=1}^{n} \xi_{i t} L_{i t},
$$

where $i$ indexes the asset class and $n$ is the number of assets. and

$$
r_{i t}=r_{t}^{*}+\kappa_{i}
$$

where the bank's lending rate $r_{i t}$ for asset $i$ is the sum of the basic borrowing/lending rate $r_{t}^{*}$ and the risk premium $\kappa_{i}$ of that asset. The total costs for the bank are then given by the sum of individual costs: ${ }^{16}$

$$
h\left(L_{t}\right)=\sum_{i=1}^{n} \eta_{i} L_{i t}+\frac{\psi_{i}}{2} L_{i t}^{2} .
$$

Finally, the balance sheet identity becomes:

$$
\sum_{i=1}^{n} L_{i t}=D_{t}+E_{t}
$$

With these simple extensions, model 2 now captures the important trade-off among assets. In the following two propositions, we first look at the impact of the interest rate on the level of total loans and then illustrate the trade-off among only two assets.

\footnotetext{
${ }^{15}$ In the quantitative analysis, we looked at four distinct asset classes, i.e. loans secured by real estate, commercial and industrial loans, consumer loans, and government securities.

${ }^{16}$ We allow for different levels of asset-specific origination costs. The purchase of a government security in the market is likely to involve significantly lower costs than the origination of a new commercial loan.
} 


\subsection{Steady State and Propositions}

The two models allow us to derive the steady state equilibrium in which the following propositions hold:

Proposition 1: The level of total loans increases with the interest rate and decreases with the non-repayment rate and disaster probability.

Proof: At the steady state, the level of aggregated loans $L$ is a constant and the interest rate and non-repayment rate equal to their mean values $\bar{r}$ and $\bar{\xi}$. Solving the steady states of model 1, we find:

$$
L=\frac{[(1-\bar{\xi}) r-\eta-\bar{\xi}-\nu]+\sqrt{[(1-\bar{\xi}) r-\eta-\bar{\xi}-\nu]^{2}-2 \psi\left(r^{D}-\nu\right) D}}{\psi} .
$$

After taking the first derivatives, we have $\frac{\partial L}{\partial \bar{r}}>0, \frac{\partial L}{\partial \bar{\xi}}<0$, and $\frac{\partial L}{\partial p}<0$. Therefore, the amount of loans is positively related to the interest rate and negatively related to the non-repayment rate. More detailed derivations are shown in our Internet Appendix.

This proposition is straightforward. The first part follows the law of demand and supply. As for the second part, when banks face higher default risks, thus a higher non-repayment rate or a higher disaster probability, to guarantee a stable income and shareholder value, banks tend to be more prudent in issuing loans.

Proposition 2: If a bank has two assets and one asset has an increase in interest rate, the bank will increase the holding of this asset and decrease the holding of another one.

Proof: Solving the steady states of model 2, we find:

$$
L_{1}=\frac{\left[\left(1-\bar{\xi}_{1}\right) r_{1}-\eta_{1}-\bar{\xi}_{1}\right]-\left[\left(1-\bar{\xi}_{2}\right) r_{2}-\eta_{2}-\bar{\xi}_{2}\right]+\psi_{2}(D+E)}{\psi_{1}+\psi_{2}} .
$$

The level of one asset is positively related to its own interest rate but is negatively related to the interest rate of another asset. That is $\frac{\partial L_{1}}{\partial \bar{r}_{1}}>0$ while $\frac{\partial L_{1}}{\partial \bar{r}_{2}}<0$. Therefore, when a disaster increases the demand and the interest rate of one asset (e.g., mortgage loans), facing its budget constraint, a bank will decrease the holdings of another asset (e.g., government securities). We include detailed derivations in our Internet Appendix.

These propositions and the corresponding proofs state the main results of our theoretical model. In the following subsection we will calibrate our model parameters and illustrate these two propositions more vividly with impulse response graphs. 


\subsection{Calibration and Simulation}

We calibrate the model using quarterly data for commercial banks. Some values are calculated direct from real data; others are chosen such that the steady-state values of our key financial variables match the average data statistics. Table 4 summarizes the calibrated parameters for our two models.

The non-repayment rate of an outstanding loan equals one less the loan's net loss rate. For each type of loan, the net loss is reported in the UBPR as year-to-date (YTD) net loss. ${ }^{17}$ In our calibration, we use one minus the mean of a loan's net loss divided by the notional amount as the expected value of the non-repayment rate $(\bar{\xi})$. We manually assign the non-repayment rate of government securities to be zero.

The time discount factors for banks and firms, $\gamma$ and $\beta$, are both set to be 0.95 , which is a standard value used in the literature. To determine the risk premium for each bank asset, we first take the average of each asset's interest rates over time and across states and use this value as the interest rate (name it as $\bar{r}_{i}$ ) of this asset. As at the equilibrium, the basic borrowing rate determined by firms is simply $r^{*}=1 / \beta-(1-\bar{\delta})$, we calibrate the risk premium for each asset as $\kappa=\bar{r}_{i}-(1 / \beta-(1-\bar{\delta}))$. The data are from the UBPR.

The cost parameters are chosen to match certain financial ratios between our model and the data, as can be seen in the next subsection. Other parameters are also calibrated to match the ratios of key variables. For example, the scale constant $N$ determines the level of deposits and therefore the size of the balance sheet. The dividend rate is based on the return on average equity for all U.S. banks from the Federal Reserve Bank of St. Louis.

Table 4 shows that real estate loans have the highest credit quality among the three types of loans, as indicated by the fact that it has the lowest average non-repayment rate. Every quarter, the default rate for real estate loans is around $0.5 \%$. The commercial and industrial loans have the lowest credit quality with an average non-repayment rate of $3 \%$. This difference reflects the role of collateral in promoting the timely repayment of loans and validates why real estate lending is the biggest lending business of banks (Gan, 2007; Chaney et al., 2012).

Having these calibrated parameters in hand, we show our model can generate key financial ratios that are close to real data. We can now examine the model's quantitative performance.

\footnotetext{
${ }^{17}$ The UBPR codes for the total loan, real estate loan, C\&I loan, and the consumer loan are UBPSE019, UBPSE397, UBPSE408, and UBPSE410 respectively. Since the "year-to-date net loss" refers to the cumulative loss so far this year, to calculate the quarterly net loss of a loan, we need to subtract the value of the YTD net loss in the current quarter by the value of the YTD net loss in the last quarter.
} 


\section{Table 4: Calibrated Parameters}

This table reports our calibrated parameters. The interest rate premium and components of non-repayment rates are based on the average interest rate and non-repayment rate reported in the Uniform Bank Performance Report (UBPR). We have data on real estate loans (labeled as RS), commercial and industrial loans (CI), and consumer loans (CS). Since the net losses data for the government securities are not available, we set the non-repayment rate of government securities (GS) to be zero. We fix the interest rates on deposit and government bond and let the interest rates of other assets to be the sum of the basic equilibrium rate and their corresponding risk premium. Parameters that cannot directly be calculated from the data are calibrated to match the data moments such as the capital ratio and the relative ratios among different assets.

\begin{tabular}{|c|c|c|c|c|c|c|c|}
\hline \multirow[b]{2}{*}{ Concept } & \multirow[b]{2}{*}{ Symbol } & \multirow{2}{*}{$\frac{\text { Model } 1}{\text { Total Loans }}$} & \multicolumn{4}{|c|}{ Model 2} & \multirow[b]{2}{*}{ Calibration Method } \\
\hline & & & $\mathrm{RS}$ & $\mathrm{CI}$ & CS & GS & \\
\hline $\begin{array}{l}\text { Normal time non-repayment } \\
\text { rate }(\%)\end{array}$ & $\mu$ & 2 & 0.5 & 2 & 3 & 0 & match UBPR data \\
\hline $\begin{array}{l}\text { Disaster time non-repayment } \\
\text { rate }(\%)\end{array}$ & $\xi^{*}$ & 1 & 2 & 2 & 2 & 0 & match UBPR data \\
\hline Mean interest rate $(\%)$ & $\bar{r}$ & 6.78 & 6.65 & 6.93 & 8.14 & 3.39 & interest rate data from UBPR \\
\hline Risk premium (\%) & $\kappa$ & 1.52 & 1.39 & 1.67 & 2.88 & - & $\kappa=\bar{r}-(1 / \beta-(1-\bar{\delta}))$ \\
\hline Cost (linear component) (\%) & $\eta$ & 1 & 0.5 & 0.1 & 0.1 & 0.5 & match data moments \\
\hline $\begin{array}{l}\text { Cost (quadratic component) } \\
(\%)\end{array}$ & $\psi$ & 0.01 & 0.2 & 0.5 & 0.7 & 0.5 & match data moments \\
\hline Time preference bank & $\gamma$ & 0.95 & & & & & standard value \\
\hline Scale constant of deposit & $N$ & 20 & & & & & match data moments \\
\hline Dividend rate $(\%)$ & $\nu$ & 15 & & & & & $\begin{array}{l}\text { average ROE for all U.S. } \\
\text { Banks from Federal Reserve } \\
\text { Bank of St. Louis }\end{array}$ \\
\hline Deposit interest rate (\%) & $r^{D}$ & 2.02 & & & & & interest rate data from UBPR \\
\hline $\begin{array}{l}\text { Persistence of interest rate } \\
(\%)\end{array}$ & $\rho$ & 0.4 & & & & & standard value \\
\hline Time preference firm & $\beta$ & 0.95 & & & & & standard value \\
\hline Total factor productivity & $A$ & 1 & & & & & $\begin{array}{l}\text { a scale constant; value does } \\
\text { not affect the results }\end{array}$ \\
\hline Capital share & $\alpha$ & 0.33 & & & & & standard value \\
\hline Depreciation rate (\%) & $\delta$ & 2 & & & & & $\begin{array}{l}\text { standard value for quarterly } \\
\text { depreciation rate }\end{array}$ \\
\hline
\end{tabular}


We first compare some key financial ratios generated by the model with ratios based on real data. Next, we carry out simulations to examine the effects of changes in asset prices after disasters.

\subsection{Data versus Model Moments}

In Table 5, we show the statistics of key financial ratios. The left panel shows ratios calculated based on the Call Reports data of U.S. commercial banks. To avoid extreme values caused by banks' size, we select banks with total assets between the 25th and 75th quantiles. Ratios in the right panel are based on our numerical model simulations. The simulated values are the average statistics derived from Monte Carlo simulations, drawing random realisations of the capital depreciation shock $\left(\epsilon_{t}^{\delta}\right)$ distribution. Each of the 5,000 simulations has 45 observations as our real data covers 45 quarters. The mean and median of the capital ratio indicated by the real data are $10.7 \%$ and $9.9 \%$ respectively. For the simulated capital ratio, the mean value is $9.4 \%$ in model 1 and $11.3 \%$ in model 2 ; both are reasonable values compared to the real data. The Table shows that except for the capital ratio, other financial ratios vary greatly across banks, which confirms the diversity of bank business models. Given the huge deviations in the real data, the ratios generated by our model are all in the reasonable domain.

\section{Table 5: Statistical Moments: Data vs. Model}

This table shows the statistical moments based on the real data and the simulated values of the models. The data are from the Call Reports with time horizon from 2002 to 2013 . To avoid extreme values caused by the size factor, we select banks with total assets between the 25 th and 75 th quantiles and calculate the means, medians, and standard deviations of financial ratios of interest. One the left panel, simulated values are the average statistics derived from a Monte Carlo simulation based on the shock distribution of the capital depreciation rate. We set the standard deviation of $\epsilon_{t}^{\delta}$ to be 0.01 , which is almost a $50 \%$ variation compared to the mean value of $\delta$, which is 0.02 . As our real data covers 45 quarters, we let each of our 5,000 simulations to have 45 observations.

\begin{tabular}{|c|c|c|c|c|c|c|}
\hline & \multicolumn{3}{|c|}{ Data } & \multicolumn{3}{|c|}{ Model } \\
\hline & Mean & Median & Std.Dev & Mean & Median & Std.Dev \\
\hline & & & & Model 1 & & \\
\hline Equity/Total Loans & 0.107 & 0.099 & 0.042 & 0.094 & 0.093 & 0.017 \\
\hline \multirow[t]{2}{*}{ Equity/Deposit } & 0.527 & 0.141 & 33.199 & 0.101 & 0.100 & 0.020 \\
\hline & & & & Model 2 & & \\
\hline Equity/Total Loans & 0.107 & 0.099 & 0.042 & 0.113 & 0.113 & 0.013 \\
\hline Equity/Deposit & 0.527 & 0.141 & 33.199 & 0.125 & 0.125 & 0.016 \\
\hline Loan CI/loan RS & 0.317 & 0.188 & 5.022 & 0.275 & 0.275 & 0.119 \\
\hline Loan HH/loan RS & 0.235 & 0.078 & 7.933 & 0.206 & 0.206 & 0.086 \\
\hline Gov. securities/loan RS & 0.296 & 0.115 & 2.308 & 0.050 & 0.050 & 0.045 \\
\hline
\end{tabular}


To further reduce concerns that the previously simulated financial ratios are sensitive to the choice of parameter values, we perform a number of sensitivity tests. In particular, we select the parameters that cannot be directly inferred from real data and for which empirical evidence is scarce. These parameters include the components in the cost function ( $\eta$ and $\psi$ ), the time preferences of bank and firm $(\gamma$ and $\beta$ ), and the constant scale parameter $N$ that determines the size of the balance sheet. We increase or decrease them by $10 \%$ respectively and compare the key financial ratios with the medians of the baseline model and real data. Our results in Table 6 show that the simulated moments are not sensitive to the exact values of the parameters we use. Only the ratio of government bonds to real estate loans, with a drop of $7 \%$, seems sensitive to these changes, but compared to the baseline simulation, this is still within the reasonable domain compared to real data. Other ratios change only slightly. ${ }^{18}$

\section{Table 6: Sensitivity Test of Model Parameters}

This table presents results of the sensitivity test of selected model parameters. We choose parameters that cannot be directly inferred from real data as they may suffer from some subjective arbitrariness. These parameters include $\eta, \psi, \gamma, N$ and $\beta$. We increase or decrease them by $10 \%$ and compare the key financial ratios with the medians of the baseline model and real data.

\begin{tabular}{|c|c|c|c|c|}
\hline & Data & Baseline & Parameter $+10 \%$ & Parameter $-10 \%$ \\
\hline Equity/Total Loans & 0.099 & 0.093 & 0.084 & 0.102 \\
\hline Equity/Deposit & 0.141 & 0.100 & 0.089 & 0.111 \\
\hline Equity/Total Loans & 0.099 & 0.113 & 0.091 & 0.132 \\
\hline Equity/Deposit & 0.141 & 0.126 & 0.099 & 0.149 \\
\hline Loan CI/loan RS & 0.188 & 0.272 & 0.295 & 0.252 \\
\hline Loan HH/loan RS & 0.078 & 0.205 & 0.220 & 0.191 \\
\hline Gov. securities/loan RS & 0.115 & 0.093 & 0.069 & 0.029 \\
\hline
\end{tabular}

Up to this point, we have set up our model, derived its static implications, calibrated the model to match the data and have shown that these calibrations are not particularly sensitive to any of the parameters in our model. To now see how our model can explain and justify banks' dynamic asset adjustment behavior, we simulate the effect of a natural disaster in the next section.

\footnotetext{
${ }^{18}$ Since in model 2 , cost parameters $\eta$ and $\psi$ are vectors, we can change values for each individual element rather than uniformly increase or decrease values by $10 \%$. We did try $10 \%$ deviations for each individual element and the results remain robust.
} 


\section{Simulation of a Disaster}

In this part, we simulate the effect of a natural disaster that is assumed to destroy production capital and by proposition 1 stimulate the demand for loans; the interest rate then increases as a result of the reduced capital stock and increased investment need. We explore how these changes can affect a bank's asset allocation. In both model 1 and model 2, we simulate a $1 \%$ increase in the capital depreciation rate. We use a $1 \%$ change in the capital depreciation rate as an example because the quarterly capital depreciation rate is $2 \%$ according to the literature (Bachmann et al., 2013); therefore, a 1\% change can proxy a large shock induced by a rare disaster as included in our empirical analysis. Our model in this study provides one explanation among many about banks' asset allocation behavior; we do not, however, intend to match every simulated number exactly with the empirical findings.

For model 1, as shown in Figure 3, the capital level drops after a disaster. Firms' marginal productivity of capital increases and they need more investment to restore production, so the lending rate increases. In response to these changes, the bank increases its origination of total loans by about $0.8 \%$ (the red curve). As a result, the bank earns more interest income and increases its equity level by about $8 \%$. Furthermore, the bank boosts its capital adequacy by more than $0.5 \%$. In brief, as the bank extends new credit, our model implies a positive role for commercial banks in supporting the economic recovery. But of course a natural disaster is not only a positive shock to firms' depreciation rates. It also affects their ability to service outstanding debt (negatively) and thereby affects the ability and willingness of banks to issue new loans.

In a more realistic scenario, we therefore assume the depreciation rate and the nonrepayment rate to be correlated. That is, a disaster destroys firm capital, interrupts production, and leads to delayed loan payment or even a default. If we assume that a $1 \%$ increase in depreciation rate is associated with a $0.5 \%$ increase in the non-repayment rate, then, as indicated by the green curves, banks will generate fewer new loans and all other variables increase to a lower amount compared to the previous case.

Figure 4 shows the effects of a disaster on different assets based on model 2. The impact of the disaster on the production sector is the same as for model 1. The difference is that, when we consider multiple assets, we see the bank increases the origination of all types of loans as the interest rates increase, but at the same time decreases its holdings of government bonds. Specifically, our model implies a roughly $4 \%$ increase in every type of loan and a $60 \%$ decrease in 


\section{Figure 3: Effects of a 1\% Increase in the Capital Depreciation Rate on Loan Orig-}

ination, Equity, Capital Ratio (or Equity Ratio), and Income (Model 1).

This figure shows the percentage deviations of loans, equity, income, firm capital, and interest rate from their steady states and the change in the capital ratio if the capital depreciation rate $\delta$ increase by $1 \%$ after a disaster based on model 1 . The green lines represent the case when the depreciation rate and non-repayment rate $\xi$ are correlated; we assume that a $1 \%$ increase in depreciation rate is associated with a $0.5 \%$ increase in the non-repayment rate. The previous five periods (i.e. -5 to -1 ) are interpolated as peaceful periods to improve the readability of the figure.
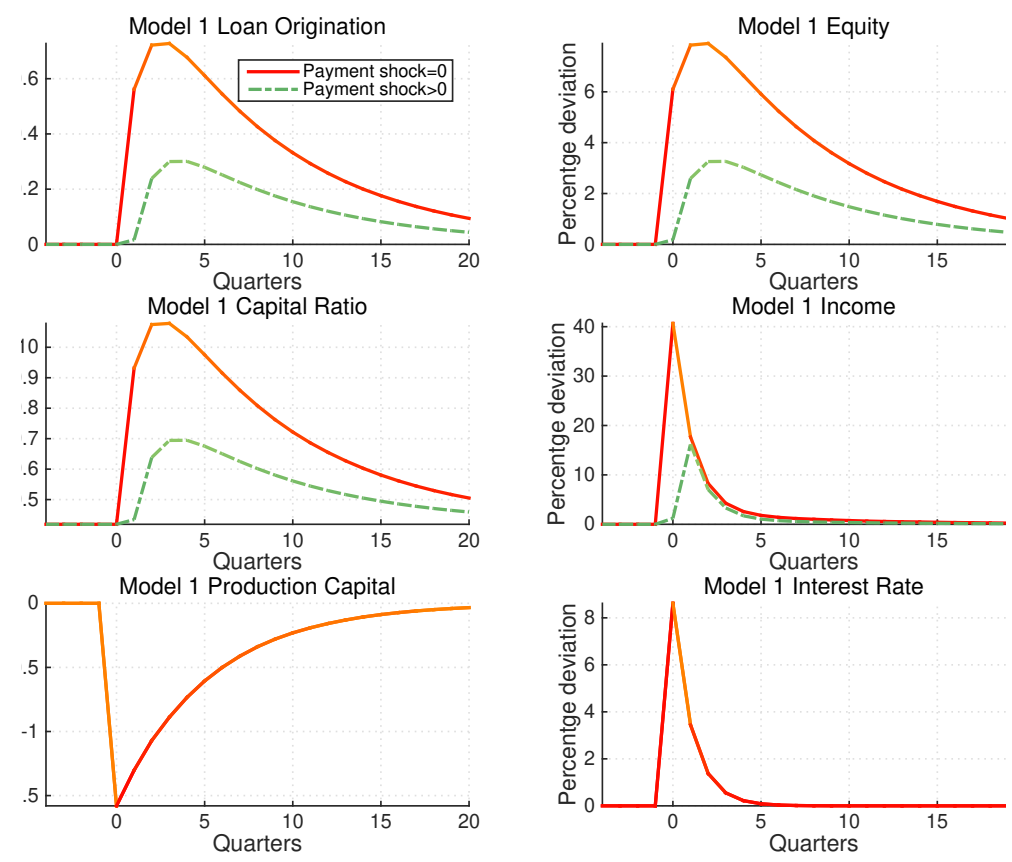

government securities. Such a reallocation compares well with our empirical findings. Our model consistently predict increases in real estate and consumer lending and decreases in government securities.

There are, however, two differences. The first is related to the change of commercial loans. As indicated by our empirical findings so far, banks decrease the origination of commercial loans after disasters whereas the simulation here implies an increase. This is because we did not consider the correlation between the depreciation and non-repayment rate so far. As commercial loans are riskier than real estate loans and are more prone to disaster-related defaults, the nonrepayment rate may increase after disasters, especially for this category of assets. We show in the Internet Appendix that when a $1 \%$ increase in the capital depreciation rate is associated with $0.5 \%$ increase in the non-repayment rate in the commercial loan, both the direction and magnitude of the changes in loans are in line with our empirical findings.

The second difference concerns the magnitude of the change in government bonds. The 
Figure 4: Effects of a 1\% Increase in the Capital Depreciation Rate on Bank Assets, Equity, Capital Ratio, and Income (Model 2). This figure shows the percentage deviations of bank assets and income from their steady states if the capital depreciation rate $\delta$ increase by $1 \%$ after a disaster based on model 2. The abbreviations RS, CI, and CS mean real estate loans, commercial and industrial loans, and consumer loans. The previous five periods (i.e. -5 to -1 ) are interpolated as peaceful periods to improve the readability of the figure.
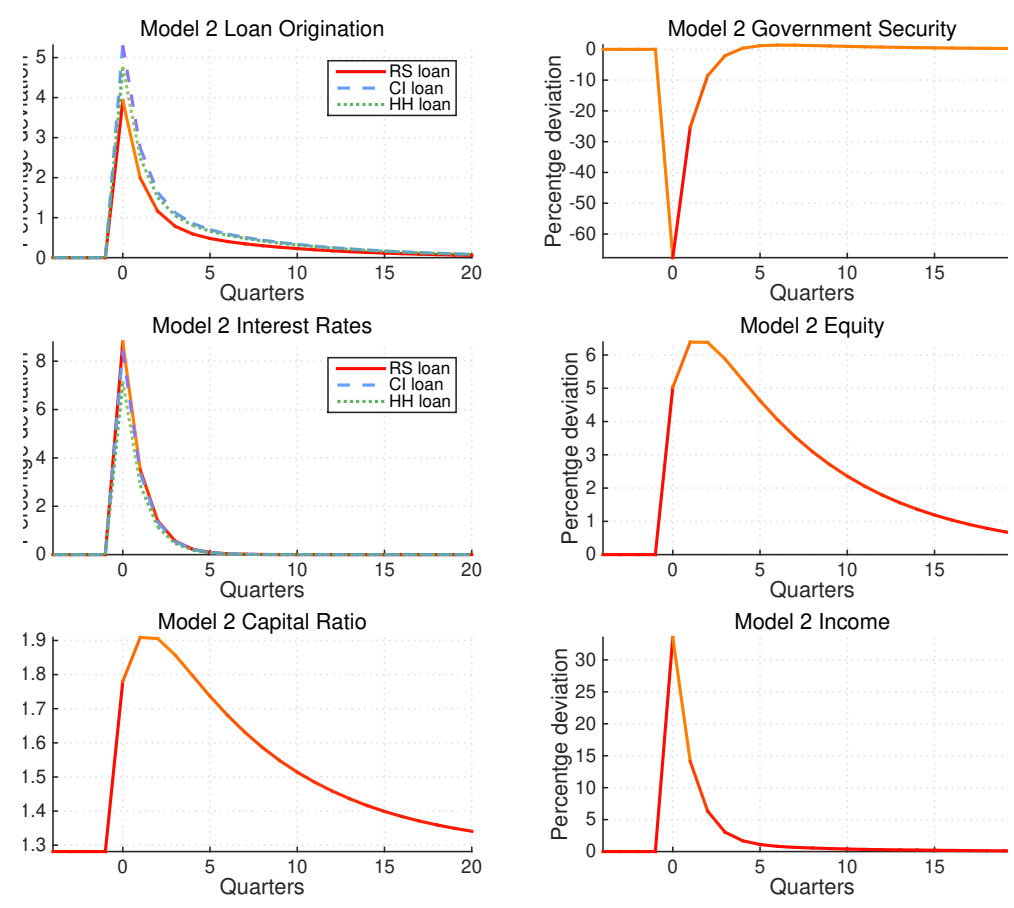

simulation implies quite a large (60\%) drop while the empirical findings reveal the drop to be around $4 \%$. As we have stated, in this study we highlight banks' use of an internal asset diversification strategy in response to disasters. Banks of course can have many other solutions to endure disasters. In previous research, Cortés and Strahan (2017) have shown that banks adjust lending between affected and unaffected regions. If banks use many strategies to cope with disasters, then the drop in the holdings of government bonds will be smaller. Also, in the data, the responses of other banks and the central bank may play a role in maintaining funding for banks in affected counties. Nevertheless, the gap to be explained here, remains large, and is likely to be the result of the fact that we allow no other way for banks to accommodate the shock from a natural disaster other than through asset reallocation.

We conclude that with a dynamic multiple-asset credit rationing model, we can explain why and how banks adjust their asset structure in response to natural hazards. By strategically (re)allocating assets, banks not only meet the increased loan demand of the local community, but also guarantee a stable income and shareholder value for themselves. In the next section, 
we go a step further by looking at the impact of climate change on banks' asset structure.

\section{Does Climate Change Affect Banks' Asset Structure?}

So far, we have explored the impact of the realization of a disaster, given the setup of our model, as calibrated to the data. In the final part of our analysis, we study what happens if the probability of a disaster happening changes, as a result of climate change. As has been predicted by the Intergovernmental Panel on Climate Change (IPCC), global warming can increase the chance of natural hazards, especially floods and hurricanes that accounts for a large portion of the disaster sample in our empirical analysis (Pachauri et al., 2014). Therefore, we present four scenarios of permanent changes of disaster probability, i.e. $+10 \%,+5 \%,-5 \%$, and $-10 \%{ }^{19}$

As shown in Figure 5, consistent with Proposition 1 in our static analysis, model 1 implies that an increase in disaster probability leads to decreased loan origination, income, equity. This is because higher disaster probability means higher expected non-repayment rate and lower income and shareholder value. As a result, banks generate less credit. Since equity decreases more than loans, the capital ratio also decreases. Therefore, our model implies that climate change not only reduces banks' ability of issuing credit, but also affects banks' stability since they maintain less capital.

As for model 2, consistent with Proposition 1, Figure 6 shows that a higher disaster probability leads to a lower level of all types of loans. However, in line with Proposition 2, banks increase the holdings of government bonds. This is because government bonds have a zero nonrepayment rate that is independent of the disaster risk and are therefore a safer asset compared to loans. Similar to the predictions of model 1, in model 2, banks' income, equity, and capital ratio also decrease in response to climate change induced increased probabilities of disaster.

To sum up, by assuming different changes in disaster probability due to climate change, our model shows that profit maximizing banks will increase their holdings of government securities and reduce their loans to firms and households. This is detrimental to their income and ultimately their reserve and equity ratios. Climate change thus hinders banks' capacity of issuing credit to productive investment and reduces banks' capital adequacy, reducing investment and negatively affecting financial stability.

\footnotetext{
${ }^{19}$ We included the negative shocks to verify that our model is symmetric in its response to the change in perceived natural disaster probabilities.
} 

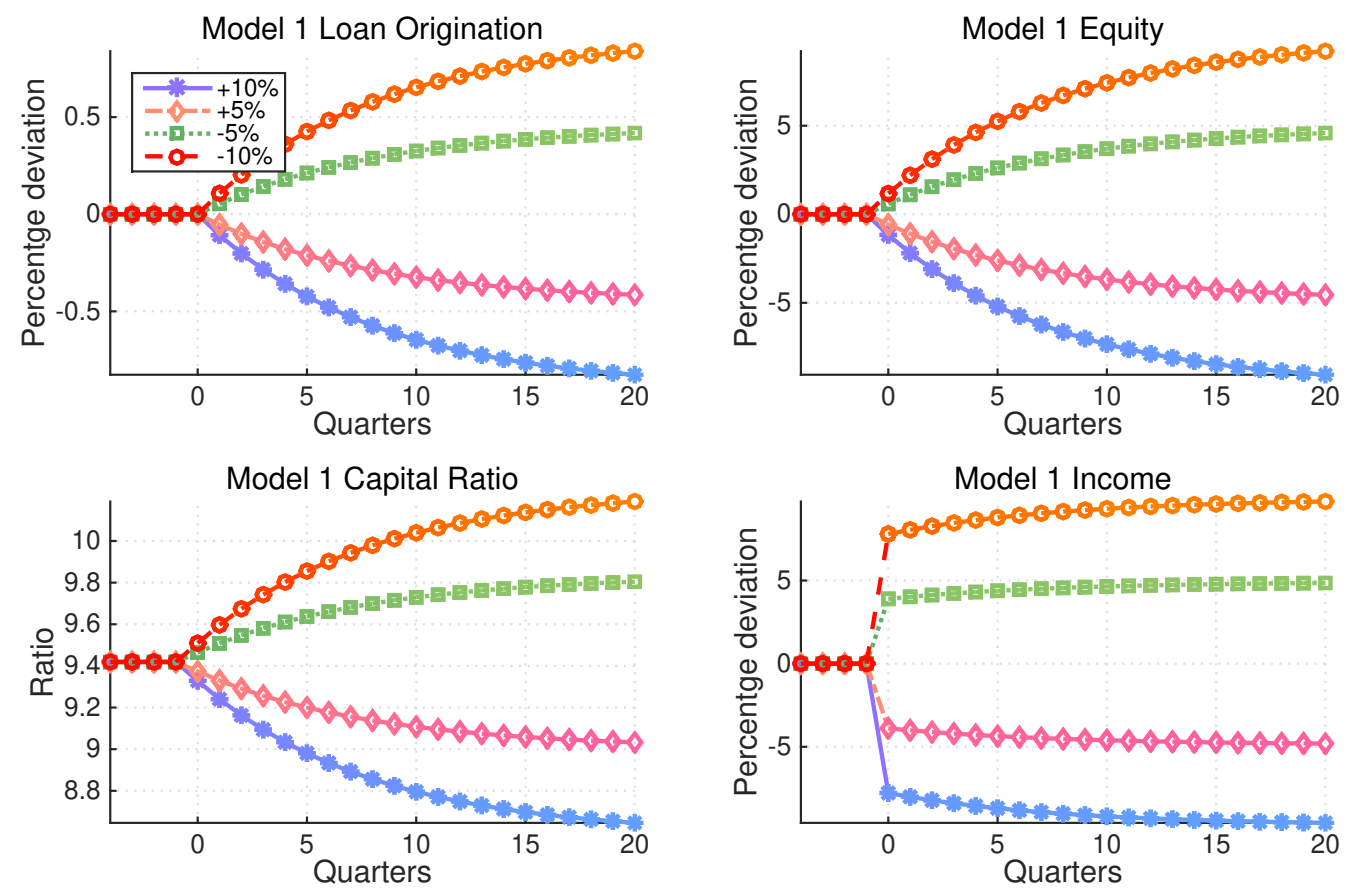

Figure 5: Effects of Different Permanent Shocks to Disaster Probability. In this figure, we assume four different scenarios about the change of disaster probability. We assume permanent changes of quarterly disaster probability to be $+10 \%,+5 \%,-5 \%$, and $-10 \%$ respectively. We have scenarios of increased probability because climate change can increase the chance of natural disasters. We also show scenarios of decreased probability to compare them with the implications of climate change. 

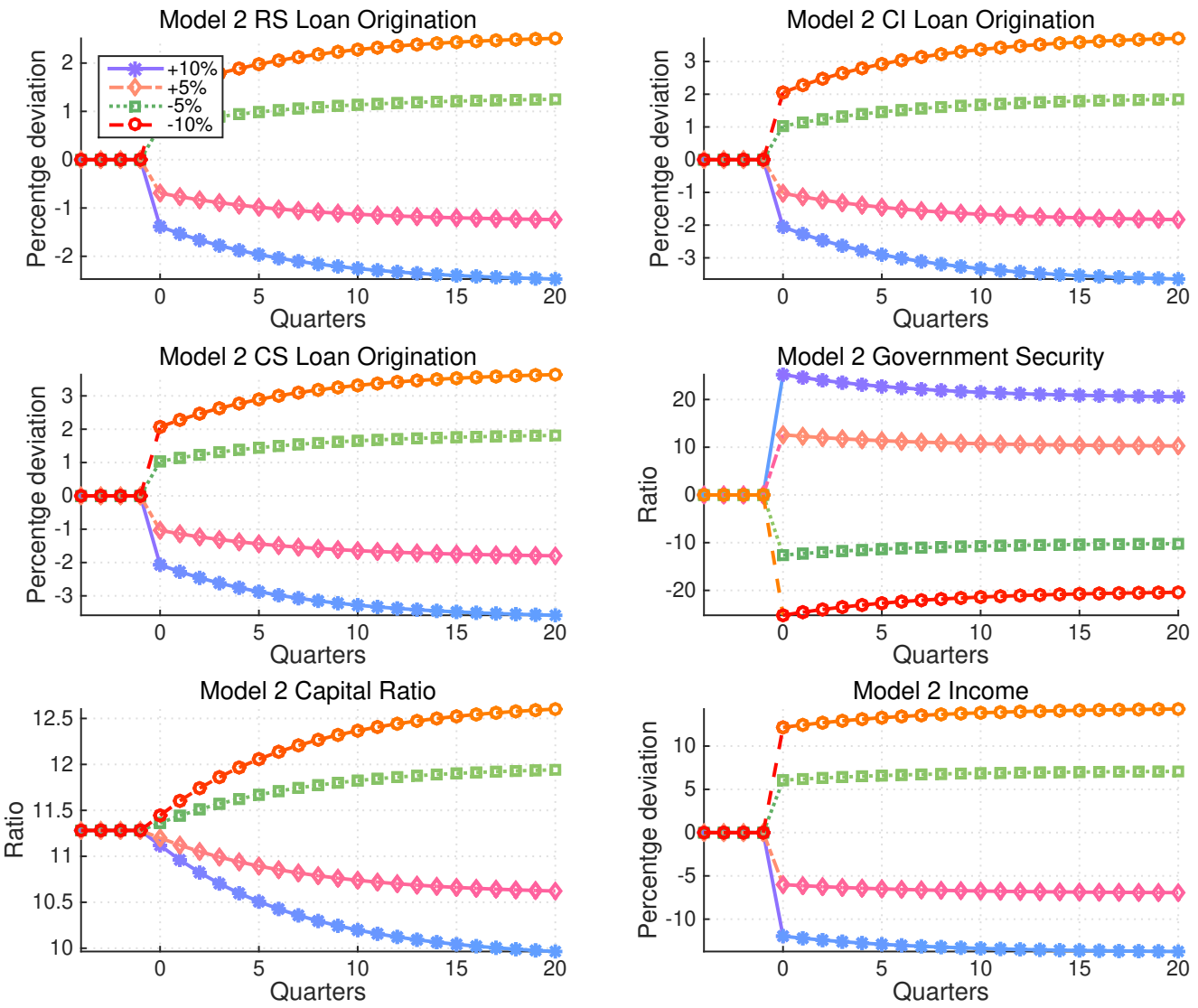

Figure 6: Effects of Different Permanent Shocks to Disaster Probability. In this figure, we assume four different scenarios about the change of disaster probability. We assume permanent changes of quarterly disaster probability to be $+10 \%,+5 \%,-5 \%$, and $-10 \%$ respectively. We have scenarios of increased probability because climate change can increase the chance of natural disasters. We also show scenarios of decreased probability to compare them with the implications of climate change. 


\section{Conclusion}

This paper examines how banks strategically reallocate their assets when natural disasters stimulate the demand for loans as was found in previous literature. In the empirical analysis, we find that natural disasters affect banks' asset structure. The changes are both statistically and economically significant. Specifically, banks increase loans secured by real estate and sell government securities to finance the increased demand for credit. Further, after a disaster small banks experience larger fluctuations in the level of assets than large banks, since the former have tighter budget constraints and/or less flexibility of diversifying assets internally.

In the theoretical part, we then develop a multiple-asset dynamic credit rationing model to explain these empirical findings. Our model includes both the supply and demand side and it illustrates how profit maximizing banks will respond to natural disasters as well as to changing underlying risks that can be linked to climate change. The model captures banks' asset allocation behavior found in the empirical analysis and has important implications for the debate on the economic impacts of climate change. First, our simulations show that higher risks of natural disaster will erode banks ability and willingness to give credit to local firms. In anticipation of more frequent and more serious weather related disasters, banks will show a rational 'flight to safety' investing more in low yielding government securities. Such behavior is individually rational, as banks anticipate interest rate hikes in post disaster investment booms, but in the long run, this will erode their capital base and financial stability in disaster prone areas. The only good news in our climate change scenarios is that governments will be able to finance deficits resulting from financial crises and natural disaster relief more cheaply. We believe, however, that both banks and society would benefit if credit allocation remains a forprofit business and banks are not forced not retreat from what is their core business. Preventing climate change would of course be a first best solution, but if adaptation is required, a natural disaster relief fund or loan insurance schemes could be considered. 


\section{References}

Acemoglu, D., Ozdaglar, A., and Tahbaz-Salehi, A. (2015), "Systemic risk and stability in financial networks," The American Economic Review, 105, 564-608.

Allen, F. and Gale, D. (2000), "Financial contagion," Journal of Political Economy, 108, 1-33.

Angbazo, L. (1997), "Commercial bank net interest margins, default risk, interest-rate risk, and off-balance sheet banking," Journal of Banking $\&$ Finance, 21, 55-87.

Asea, P. K. and Blomberg, B. (1998), "Lending cycles," Journal of Econometrics, 83, 89-128.

Bachmann, R., Elstner, S., and Sims, E. R. (2013), "Uncertainty and economic activity: Evidence from business survey data," American Economic Journal: Macroeconomics, 5, 217-49.

Barro, R. J. (2006), "Rare disasters and asset markets in the twentieth century," The Quarterly Journal of Economics, 121, 823-866.

- (2009), "Rare disasters, asset prices, and welfare costs," The American Economic Review, 99, 243-264.

- (2015), "Environmental protection, rare disasters and discount rates," Economica, 82, 1-23.

Berg, G. and Schrader, J. (2012), "Access to credit, natural disasters, and relationship lending," Journal of Financial Intermediation, 21, 549-568.

Bernanke, B. S. and Gertler, M. (1989), "Agency costs, net worth, and business fluctuations," The American Economic Review, 79, 14-31.

Broaddus, A. (1972), "Linear programming: a new approach to bank portfolio management," Monthly Review, Federal Reserve Bank of Richmond, 3.

Brunnermeier, M. K., Eisenbach, T. M., and Sannikov, Y. (2012), "Macroeconomics with financial frictions: A survey," Working paper, No. w18102. National Bureau of Economic Research. Available at: http://www.nber.org/papers/w21997.

Carling, K. and Lundberg, S. (2005), "Asymmetric information and distance: an empirical assessment of geographical credit rationing," Journal of Economics and Business, 57, 39-59.

Carlstrom, C. T. and Fuerst, T. S. (1997), "Agency costs, net worth, and business fluctuations: A computable general equilibrium analysis," The American Economic Review, 87, 893-910. 
Chaney, T., Sraer, D., and Thesmar, D. (2012), "The collateral channel: How real estate shocks affect corporate investment," American Economic Review, 102, 2381-2409.

Chavaz, M. (2014), "Riders of the storm: Economic shock and bank lending in a natural experiment," Working paper No. 617, Bank of England. Available at: https://www.rsm.nl/ fileadmin/home/Department_of_Finance__VG5_/ECC2014/Final_Papers/Chavaz.pdf.

Collier, B. (2014), "Natural disasters and credit supply shocks," Working paper No. 2014-02, University of Pennsylvania. Available at: http://opim.wharton.upenn.edu/risk/library/ WP201402_BLC_Disasters+CreditSupply.pdf.

Cortés, K. R. (2017), "How Small Banks Deal with Large Shocks," Economic Commentary, 05.09.17.

Cortés, K. R. and Strahan, P. E. (2017), "Tracing out capital flows: How financially integrated banks respond to natural disasters," Journal of Financial Economics, 125, 182-199.

Dlugosz, J., Gam, Y., Gopalan, R., and Skrastins, J. (2018), "Decision-making delegation in banks," Working Ppaer, available at https://ssrn.com/abstract=3155683.

Gabaix, X. (2008), "Variable rare disasters: A tractable theory of ten puzzles in macro-finance," The American Economic Review, 98, 64-67.

Gan, J. (2007), "Collateral, debt capacity, and corporate investment: Evidence from a natural experiment," Journal of Financial Economics, 85, 709-734.

Gorton, G. B. and He, P. (2008), "Bank credit cycles," The Review of Economic Studies, 75, $1181-1214$.

Gourio, F. (2012), "Disaster risk and business cycles," The American Economic Review, 102, $2734-2766$.

Guha-Sapir, D., Below, R., and Hoyois, P. (2015), "EM-DAT: the CRED/OFDA international disaster database. Université Catholique de Louvain, Brussels, Belgium," .

Hannan, T. H. and Berger, A. N. (1991), "The rigidity of prices: Evidence from the banking industry," The American Economic Review, 81, 938-945.

Iacoviello, M. (2005), "House prices, borrowing constraints, and monetary policy in the business cycle," The American Economic Review, 95, 739-764. 
Jaffee, D. M. and Modigliani, F. (1969), "A theory and test of credit rationing," The American Economic Review, 59, 850-872.

Klein, M. A. (1970), "Imperfect asset elasticity and portfolio theory," The American Economic Review, 60, 491-494.

— (1971), "A theory of the banking firm," Journal of Money, Credit and Banking, 3, 205-218.

Klomp, J. (2014), "Financial fragility and natural disasters: An empirical analysis," Journal of Financial Stability, 13, 180-192.

Koetter, M., Noth, F., and Rehbein, O. (2016), "Borrowers under water! Rare disasters, regional banks, and recovery lending," Working paper No. 31/2016, Halle Institute for Economic Research (IWH). Available at: https://www.econstor.eu/bitstream/10419/148305/1/ 873347188.pdf.

Loayza, N., Olaberria, E., Rigolini, J., and Christiaensen, L. (2009), "Natural disasters and growth-going beyond the averages," World Bank Policy Research Working Paper Series, Vol.

Markowitz, H. (1952), "Portfolio selection," The Journal of Finance, 7, 77-91.

Merton, R. C. (1969), "Lifetime portfolio selection under uncertainty: The continuous-time case," The Review of Economics and Statistics, 51, 247-257.

Noy, I. (2009), "The macroeconomic consequences of disasters," Journal of Development Economics, 88, 221-231.

Pachauri, R. K., Allen, M. R., Barros, V. R., Broome, J., Cramer, W., Christ, R., Church, J. A., Clarke, L., Dahe, Q., Dasgupta, P., et al. (2014), Climate change 2014: synthesis report. Contribution of Working Groups I, II and III to the fifth assessment report of the Intergovernmental Panel on Climate Change, IPCC.

Pagano, M. (1993), "Financial markets and growth: An overview," European Economic Review, $37,613-622$.

Porter, R. C. (1962), A model of bank portfolio selection, vol. 88, Cowles Foundation Discussion Papers.

Pringle, J. J. (1974), "The imperfect-markets model of commercial bank financial management," Journal of Financial and Quantitative Analysis, 9, 69-87. 
Rietz, T. A. (1988), "The equity risk premium a solution," Journal of Monetary Economics, $22,117-131$.

Samuelson, P. A. (1969), "Lifetime portfolio selection by dynamic stochastic programming," The Review of Economics and Statistics, 51, 239-246.

Schüwer, U., Lambert, C., and Noth, F. (2018), "How do banks react to catastrophic events? Evidence from Hurricane Katrina," Review of Finance, 22, 419-847.

Sealey, C. W. (1980), "Deposit Rate-Setting, Risk Aversion, and the Theory of Depository Financial Intermediaries," The Journal of Finance, 35, 1139-1154.

Slovin, M. B. and Sushka, M. E. (1983), "A model of the commercial loan rate," The Journal of Finance, 38, 1583-1596.

Stiglitz, J. E. and Weiss, A. (1981), "Credit rationing in markets with imperfect information," The American Economic Review, 71, 393-410.

Sun, H. (2016), "Crisis-Contingent Dynamics of Connectedness: An SVAR-Spatial-Network Tripod Model with Thresholds (Job Market Paper)," GSBE Research Memorandum, Maastricht University, 032.

Toya, H. and Skidmore, M. (2007), "Economic development and the impacts of natural disasters," Economics Letters, 94, 20-25.

Wachter, J. A. (2013), "Can Time-Varying Risk of Rare Disasters Explain Aggregate Stock Market Volatility?" The Journal of Finance, 68, 987-1035.

Zecchini, S. and Ventura, M. (2009), "The impact of public guarantees on credit to SMEs," Small Business Economics, 32, 191-206. 


\section{Appendix}

\section{Table 7: Terminology}

This table presents definitions of all the terminologies related to natural disasters and banking variables used through out the paper as well as their abbreviations. The definitions of the banking variables can be found in the instructions of the Call Reports compiled by the Federal Deposit Insurance Corporation (FDIC).

Natural disaster

Loans secured by real estate (RS)

Commercial and industrial loans

Consumer loans (CS)

Government securities (GS)

Interest-bearing deposits (DP)

Loans Net Losses (\%)
A natural disaster is a major adverse event resulting from natural processes of the Earth; examples include floods, volcanic eruptions, earthquakes, tsunamis, and other geologic processes. A natural disaster can cause loss of life or property damage, and typically leaves some economic damage in its wake, the severity of which depends on the affected population's resilience, or ability to recover. ${ }^{1}$

A loan secured by real estate is a loan that, at origination, is secured wholly or substantially by a lien or liens on real property for which the lien or liens are central to the extension of the credit - that is, the borrower would not have been extended credit in the same amount or on terms as favorable without the lien or liens on real property.

Loans for commercial and industrial purposes to sole proprietorships, partnerships, corporations, and other business enterprises, whether secured (other than those that meet the definition of a "loan secured by real estate") or unsecured, singlenonrepayment or instalment. ${ }^{2}$

In this category, a bank will report all its credit extended to individual for household, family, and other personal expenditures that does not meet the definition of the loans secured by real estate. It includes credit cards, other revolving credit plans, automobile loans, and other consumer loans.

This variable is a combination of two categories in the call report: 1) U.S. Treasury securities: amortized cost and fair value of all U.S. Treasury securities not held in trading accounts. It should include all bills, certificates of indebtedness, notes, and bonds. 2) U.S. Government agency obligations: the amortized cost and fair value of all U.S. Government agency obligations not held for trading. But the mortgagebacked securities are excluded. ${ }^{3}$

Interest-bearing deposits accounts consist of deposits accounts on which the issuing depository institution makes any nonrepayment to or for the account of any depositor as compensation for the use of funds constituting a deposits.

The year-to-date net loss (change offs less recoveries) for the gross (or a specific type of) loans divided by average gross (or a specific type of) loans. ${ }^{4}$

\footnotetext{
${ }^{1}$ This definition is from Wikipedia-Natural Disaster.

2 The Loan and Lease part, schedule RC-C has two parts, the second of which is "Loans to Small Businesses and Small Farms". But the first part already includes the second part.

3 The definitions of the above bank assets are from each individual schedules of the Reports of Condition and Income Instruction Book (Updated June 2015).

${ }^{4}$ Year-to-date (YTD) net loss refers to the loss so far this year. To calculate the net loss in the 3rd quarter, we need to subtract the value of 3rd quarter YTD net loss by the value of 2nd quarter YTD net loss.
} 


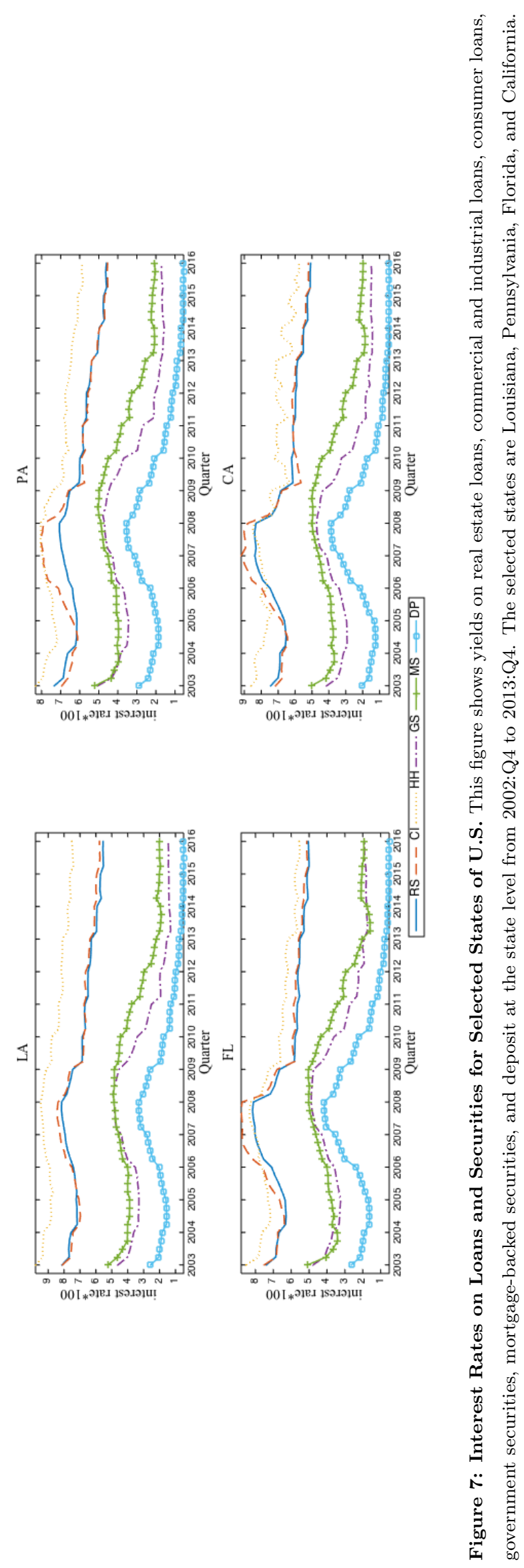


Table 8: List of Significant Natural Disasters in the US: 2001 to 2015

\begin{tabular}{|c|c|c|c|c|}
\hline Year & State Mainly Affected & Type & Name & Total Damage (Million) \\
\hline 2005-08/09 & Louisiana & Tropical storms and cyclones & Hurricane Katrina & 125000 \\
\hline $2012-10$ & New York & Tropical storms and cyclones & Hurricane Sandy & 80000 \\
\hline 2004-08 & Florida & Tropical storms and cyclones & $\begin{array}{l}2004 \text { Atlantic } \\
\text { Hurricane Season; } \\
\text { Hurricane Frances, } \\
\text { Ivan }\end{array}$ & 18000 \\
\hline 2005-09 & Louisiana & Tropical storms and cyclones & Hurricane Rita & 16000 \\
\hline 2004-09 & Florida & Tropical storms and cyclones & $\begin{array}{l}2004 \text { Atlantic } \\
\text { Hurricane Season; } \\
\text { Hurricane Frances, } \\
\text { Ivan }\end{array}$ & 12000 \\
\hline $2008-06$ & Missouri & Floods & $\begin{array}{l}\text { June } 2008 \text { Midwest } \\
\text { floods }\end{array}$ & 10000 \\
\hline 2001-06 & Louisiana & Tropical storms and cyclones & $\begin{array}{l}2001 \text { Atlantic } \\
\text { Hurricane Season; } \\
\text { Hurricane Allison }\end{array}$ & 6000 \\
\hline 2003-09 & North Carolina & Tropical storms and cyclones & Hurricane Isabel & 5000 \\
\hline 2011-04/05 & Arkansas & Floods & $\begin{array}{l}2011 \text { Mississippi River } \\
\text { Floods }\end{array}$ & 3000 \\
\hline $2010-04 / 05$ & Tennessee & Floods & 2010 Tennessee Floods & 2350 \\
\hline 2011-05/06 & Iowa & Floods & $\begin{array}{l}2011 \text { Missouri River } \\
\text { Floods }\end{array}$ & 2000 \\
\hline 2001-02 & Washington & Earthquakes & $\begin{array}{l}2001 \text { Nisqually } \\
\text { earthquake }\end{array}$ & 2000 \\
\hline 2013-09 & Colorado & Floods & 2013 Colorado floods & 900 \\
\hline 2011-08 & Pennsylvania & Floods & $\begin{array}{l}2011 \text { Atlantic } \\
\text { Hurricane Season; } \\
\text { Tropical Storm Lee }\end{array}$ & 1200 \\
\hline 2011-09 & Mississippi & Tropical storms and cyclones & $\begin{array}{l}\text { 2011Atlantic } \\
\text { Hurricane Season; } \\
\text { Tropical Storm Lee }\end{array}$ & 1000 \\
\hline 2006-06 & Pennsylvania & Floods & $\begin{array}{l}\text { Mid-Atlantic United } \\
\text { States flood of } 2006\end{array}$ & 1000 \\
\hline $2002-07$ & Texas & Floods & $\begin{array}{l}\text { Late June and Early } \\
\text { July Floods of } 2002\end{array}$ & 1000 \\
\hline
\end{tabular}

